\title{
SOVEREIGN WEALTH FUNDS
}

DO SOVEREIGN WEALTH FUNDS BEST SERVE THE INTERESTS OF THEIR RESPECTIVE CITIZENS?

\author{
John Blackburn \\ Brent DelVecchio \\ Ira Fox \\ Carl Gatenio \\ Omar Khayum \\ Daniel Wolfson
}

March 24, 2008 
Sovereign Wealth Funds (SWFs) have been the subject of extensive media coverage in recent months. Their increasing prevalence and size coupled with a series of substantial investments in high-profile companies and, in many instances, the opacity of their operations have all fueled intense debate regarding their intentions, their governance, and their place in global financial markets. As their relative size increases, and they play a larger role in financial markets across the globe, these funds will become an important topic in economics. Much of the popular rhetoric has argued the issue through the lens of investment recipients. In this paper we aim to take a different perspective -- the perspective of the citizens of the countries controlling the SWFs. Specifically, we attempt to determine whether SWFs best serve the interests of those citizens.

In order to answer that question we identify and evaluate potential benefits SWFs can offer their citizens and then weigh them against possible alternative uses of the funds. The potential benefits that we identified are the ability of SWFs to earn higher risk-adjusted returns than other investments and the additional political leverage that a government can wield on behalf of its citizens with the clout that a SWF gives it. The alternatives to SWFs that we'll be examining are lowering taxes and making more investments in infrastructure.

We begin our analysis by first providing a definition and an overview of SWFs and discussing the sources of their assets as well as their investment styles. Next, we explore each of the benefits of and alternatives to SWFs in general but also recognize that the applicability of the benefits and the attractiveness of the alternatives depend heavily upon the political and economic context in which the SWF operates. Therefore, following a general discussion of each of those considerations, we analyze how they apply to each of the six largest SWFs in terms of assets under management: Abu Dhabi Investment Authority (UAE), Government Pension Fund - Global (Norway), GIC and Temasek Holdings (Singapore), Kuwait Investment Authority (Kuwait), CIC (China), and Stabilization Fund (Russia). We then introduce and apply a framework to aggregate the analysis and produce a recommendation for retaining or discontinuing each SWF. In the event of the latter recommendation, we also discuss several options governments have for executing a drawdown of the fund to achieve predictable and desirable behaviors by its citizens.

\section{SOVEREIGN WEALTH FUNDS DEFINED}

What are sovereign wealth funds? Their wide diversity in terms of sources of funds, investment objectives, assets held, and management structure makes this a more difficult question to answer than one might imagine. For the purpose of our analysis we will employ the definition of SWFs adopted by the US Treasury Department: "government investment vehicles funded by foreign exchange assets and managed separately from official reserves." Official reserves, which are controlled by monetary authorities such as central banks, serve to finance payment imbalances and guard against exchange rate volatility and are therefore typically invested in safe, highly liquid securities. On the other hand, "SWF managers typically have higher tolerance for risk and seek higher returns than do official reserve managers." 2 As a consequence of being severed from the official reserves pool, SWFs also avoid inclusion in the IMF's reserves transparency systems,

${ }^{1}$ Kimmitt, Robert "Public Footprints in Private Markets". Foreign A ffairs, January/February 2008

${ }^{2}$ Ibid 
although participation in these systems is voluntary. This definition therefore excludes pools of capital such as Saudi Arabia's government's deposits of approximately $\$ 128 \mathrm{~B}$ at the Saudi Arabian Monetary Agency (SAMA), the Saudi central bank, which are invested on its behalf by SAMA, primarily in US treasuries. ${ }^{3}$

Two basic types of SWFs are distinguished by the sources of their funds. The first category is funded by commodity exports which are owned or taxed by the government, and includes the likes of the UAE's ADIA, Norway's Government Pension Fund, and Russia's Stabilization Fund. The other is financed by transfers from excess foreign exchange reserves", as is the case with Singapore's GIC and China's CIC. The main difference between the two is that non-commodity funds typically involve exchange rate interventions which require the issuance of debt to offset inflationary pressures. ${ }^{4}$ The returns of these SWFs are therefore netted by the interest on the debt bonds issued, whereas commodity funds do not incur this cost of capital.

\section{SOVEREIGN WEALTH FUND OVERVIEW}

The first SWF began in Kuwait in 1953, and the next four decades saw the introduction of few more. Since 2000, the number of new SWF has increased significantly, with at least 12 new funds in seven years, the most recent being the China Investment Corporation (CIC). There are about 35 active funds today, ranging in size from Kiribati's $\$ 400$ million fund to the UAE's $\$ 875$ billion Abu Dhabi Investment Authority (ADIA) fund. Due to limited disclosure by many funds, it is difficult to provide an exact aggregate amount under management, but most research on the topic indicates a worldwide range of $\$ 2.0-3.0$ trillion. There are currently seven funds in six nations with over $\$ 100$ billion under management: ADIA (UAE), GIC and Temasek Holdings (Singapore), Government Pension Fund - Global (Norway), Kuwait Investment Authority (Kuwait), CIC (China), and Stabilization Fund (Russia) ${ }^{5}$. These funds will be the focus of a country-specific analysis in the second half of the paper. A detailed break-down of each fund by country is available in Appendix 1; the highlights of that follow:

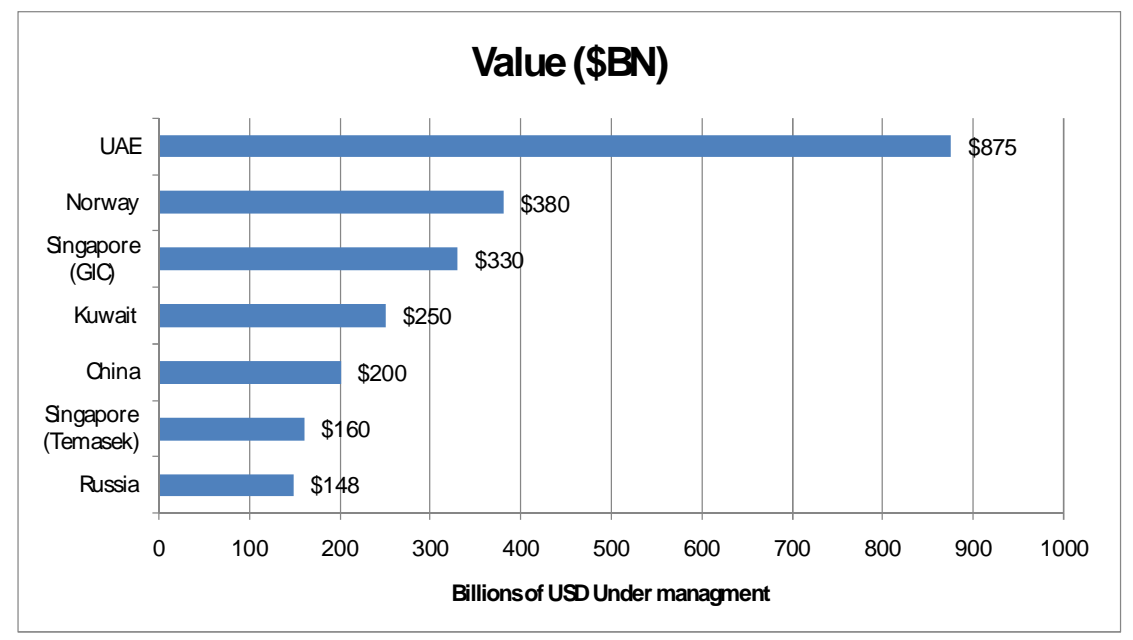

3 “NCB's Said Al-Shaikh Urges Saudi Arabia To Set Up Sovereign Fund” http://www.zawya.com/story.cfm/sidv51n03-3NC23

* The distinction of excess reserves is subject to some debate as the level of reserves necessary to defend the currency in the event of a crisis or to finance an international payment imbalance is itself contentious issue. For the purposes of our analysis, we assume central banks retain sufficient official reserves to serve the interests of their economies.

${ }^{4}$ Kimmitt, Robert "Public Footprints in Private Markets". Foreign A ffairs, January/February 2008

${ }^{5}$ Lyons, Gerald. "State Capitalism: The Rise of Sovereign Wealth Funds." Standard Chartered Bank publication (19 Oct 2007) 
The approximate current dollar amount in each SWF per citizen varies greatly and is summarized below:

\begin{tabular}{|l|r|r|}
\hline & $\begin{array}{l}\text { \$ in SWF per } \\
\text { population* }\end{array}$ & $\begin{array}{l}\text { \$ in SWF per } \\
\text { citizen }\end{array}$ \\
\hline UAE & $\$ 191,000$ & $\$ 1,273,333$ \\
\hline Kuwait & $\$ 80,645$ & $\$ 200,000$ \\
\hline Singapore & $\$ 104,255$ & $\$ 132,432$ \\
\hline Norway & $\$ 80,851$ & $\$ 89,835$ \\
\hline Russia & $\$ 1,042$ & $\$ 1,057$ \\
\hline China & $\$ 154$ & $\$ 154$ \\
\hline
\end{tabular}

Furthermore, the potential size of these funds is unknown, but a recent research report by Morgan Stanley ${ }^{6}$ approximates SWF will have $\$ 12$ trillion under management by 2015 :

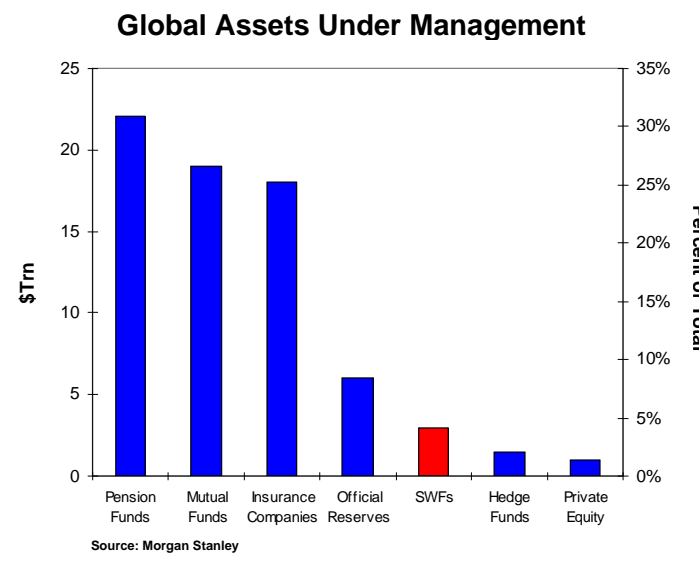

Rapid Growth of SWFs Projected (USD million)

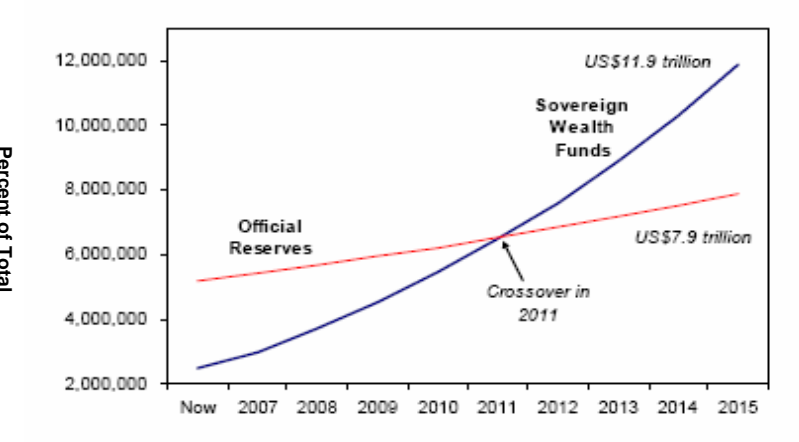

Source: Morgan Stanley Research estimates

As shown in the following chart, the governance of SWFs varies significantly. Funds can be grouped by means of funding - commodity versus non-commodity or by their transparency and investment approach. A conventional investment approach means that SWF managers use outside external money managers or make investments in foreign securities only, not in direct equity stakes. SWFs pursuing a strategic investment approach take more direct equity stakes. Note that Singapore has two funds and UAE has three.

\footnotetext{
${ }^{*}$ Countries such as the UAE have largely expatriate workforces; we have shown the differences here for comparison.

6 "Asset Backed Insecurity", The Economist, (17 Jan 2008) 78-80
} 


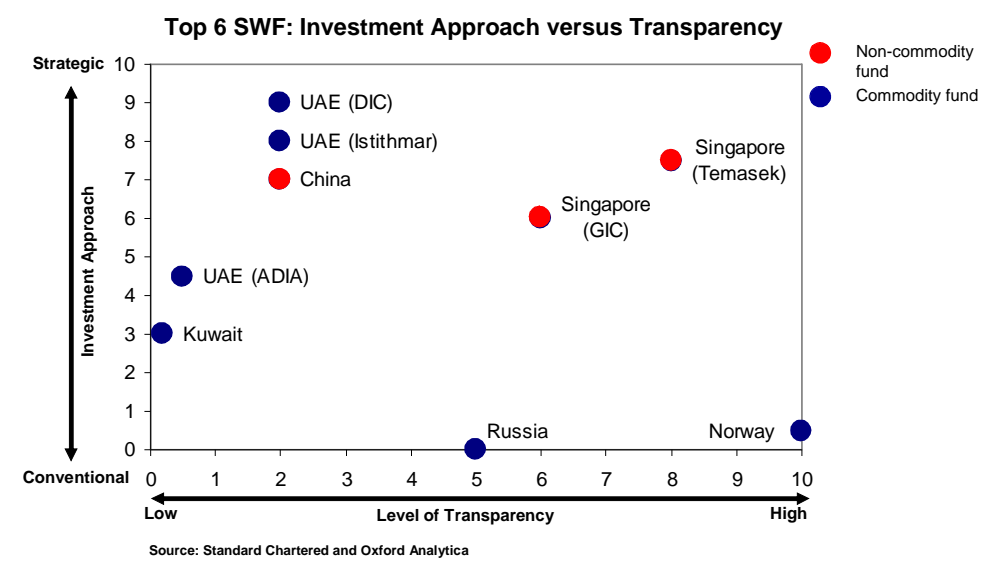

The objectives of SWFs have stirred up controversy in the actual and potential host countries of SWF investments. From the host's perspective, the SWFs objectives may be political, strategic, and/or strictly financial, but it is impossible to definitively know. The following are stated objectives of SWFs?

- Higher returns: Motivated by the opportunity cost of excess official reserves invested in risk-free assets, countries are seeking to maximize returns.

- Saving for future generations: Several funds intend to provide wealth for future generations, when natural resources are depleted and no longer providing surplus revenue to the country.

- Macroeconomic stabilization: Countries dependent on commodity exports use their SWFs to diversify their risk and smooth fluctuations in global market prices; when oil prices drop, the SWF will provide a cushion and absorb some of the shock.

- Promotion of domestic industries: Some of the funds are being used to encourage the creation and expansion of industries in their respective countries.

The types of investments the funds make also vary greatly depending on the primary purpose of fund, and its disclosure and general governance policies:

- Future generation funds tend to be very diversified and hold small stakes in their investments. For example, Norway's fund holds shares in about 3,500 companies; most stakes are less than $1 \%$.

- Stabilization funds seek to deliver moderate, low risk returns as they are limited to AAA rated sovereign bonds, with a given currency composition to manage currency risk.

- To the extent information is available, less transparent funds tend to take substantial, but noncontrolling stakes in their investments to avoid disclosure requirements.

As discussed, many funds have limited disclosure, so growth rates and returns are very difficult to quantify or separate. To the extent possible, we have included growth and return data in the summary table in the appendix. For fiscal years ending 2007, reported returns have been strong, between $8.5 \%$ in Norway and $27 \%$ for Singapore's Temasek Holdings. Existing research suggests that SWFs are growing strong, especially those funded by oil exports; as the price of oil increases (assuming extraction costs remain fairly constant or decline), the size of these funds will continue to grow. 2006-2007 annual growth rates from the largest funds ranges from $10 \%$ in UAE to $96 \%$ in Russia.

\footnotetext{
${ }^{7}$ Lyons, Gerald. "State Capitalism: The Rise of Sovereign Wealth Funds.” Standard Chartered Bank publication (19 Oct 2007)
} 


\section{INTRODUCTION TO 4-FACTOR FRAMEWORK}

In order to address our question of whether SWFs best serve the interests of their respective citizens, we developed a four-factor model that evaluates two potential benefits of SWFs and two alternatives. We focus on the six countries with the largest funds and apply the analysis to their unique political and economic landscapes. We rate each benefit and alternative with a score from -5 to +5 along each dimension of the framework. The rating system can be interpreted as follows:

\begin{tabular}{|l|l|l|}
\hline Attribute or Alternative & Positive number represents: & Negative number represents: \\
\hline Investment Environment & $\begin{array}{l}\text { Government can obtain higher return } \\
\text { than citizens* }\end{array}$ & $\begin{array}{l}\text { Citizens can obtain equal or higher } \\
\text { returns than government }\end{array}$ \\
\hline Political Gain & $\begin{array}{l}\text { The potential for political gain is } \\
\text { substantial }\end{array}$ & $\begin{array}{l}\text { The potential for political gain is } \\
\text { limited }\end{array}$ \\
\hline Lower Taxes & $\begin{array}{l}\text { SWF yields higher return than } \\
\text { lowering taxes }\end{array}$ & $\begin{array}{l}\text { SWF yields lower return than lowering } \\
\text { taxes }\end{array}$ \\
\hline Invest in Infrastructure & $\begin{array}{l}\text { SWF yields higher return than } \\
\text { investing in infrastructure }\end{array}$ & $\begin{array}{l}\text { SWF yields lower return than investing } \\
\text { in infrastructure }\end{array}$ \\
\hline
\end{tabular}

Generally, positive numbers indicate an argument for keeping the SWF and negative numbers indicate that there is a case for abolishing it. For example, if Country A has a " 5 " on Investment Returns, the government of Country A will likely obtain a much higher return on its investments than the citizens of Country A. We calculated our country level recommendations by summing the scores of the dimensions of each country. Negative scores indicate that a SWF does serve the interests of its respective citizens and a positive score indicates that a SWF does not do so and there is a better alternative use of surpluses.
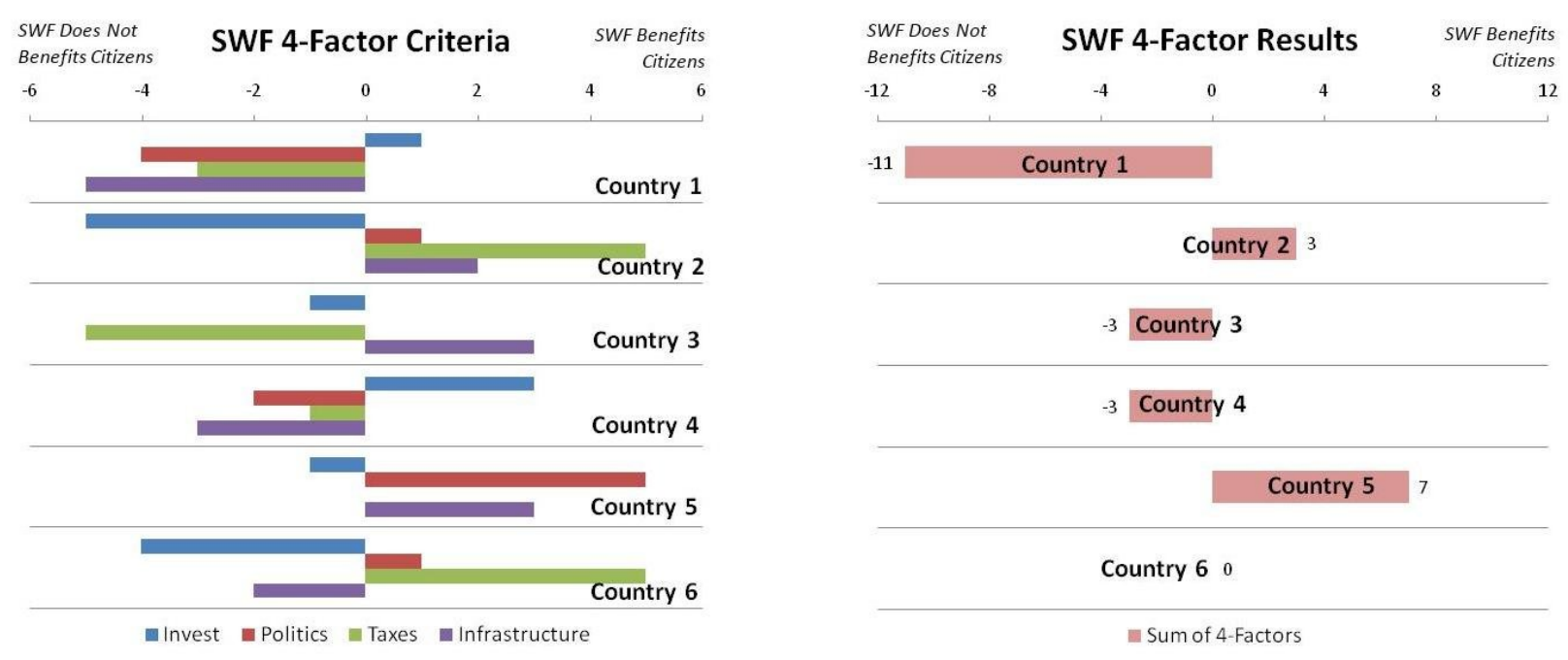

* The scoring of this factor is more complicated than just a comparison of returns - see Investment Environment section for more detail. 


\section{SOVEREIGN WEALTH FUNDS AS SAVINGS VEHICLES}

As stated earlier, SWFs commonly claim intergenerational savings as one of their primary objectives. In order to evaluate whether this purpose justifies the existence of SWFs we must compare the returns they are able to generate to the returns of alternative vehicles or approaches to saving for future generations.

The first alternative we examine applies to nations whose surpluses are earned from the sale of state-owned, non-renewable resources, namely oil. Given that these nations would like to save part of their natural resource wealth for the future, should they extract and sell their resources at current market prices, or are citizens and future generations better served by leaving more of the oil supply in the ground for sale at future prices? In order to address this question we will first examine the historical changes in the price of oil relative to other assets, and then use projections of future oil prices to establish a hurdle rate that SWFs must meet in order to justify the decision their governments have made to sell the commodities and invest the proceeds today.

Next, given the hurdle rate we determine in the first part of our analysis, we will examine whether the private sector or the public sector (via SWFs) is better suited to save for the future by comparing the investment environment and rates of return each can expect to earn. The level of access that citizens have to financial markets can significantly influence expected private sector returns and it varies substantially across countries with SWFs. Although a strong case can be made for the benefits of opening up the economies in question for individuals to invest abroad, we will take the current states of the economies as given for the purposes of our analysis. We will also explore other factors affecting the relative returns of SWFs and private investment vehicles including differences in tax treatment, management fees, and degrees of transparency.

THE DECISION TO EXTRACT NON-RENEWABLE NATURAL RESOURCES

Hotelling's Rule suggests that in order to maximize the present value of returns to a non-renewable natural resource, producers should supply output to the point where the projected rate of increase in unit profits equals the rate of return that owners of the resource can earn from alternative investments. Mathematically, that relationship is represented as follows:

Hotelling's Rule: $\mathbf{P}^{\prime}(\mathrm{t}) / \mathbf{P}(\mathrm{t})=\delta$, where $\mathrm{P}(\mathrm{t})$ is resource unit profit (market price - extraction cost) at time $\mathrm{t}$ and $\delta$ is the discount rate.

If the projected rate of unit profit increase is greater than the opportunity cost of capital, then producers should restrict output to sell more at future, higher prices until the current price increases sufficiently to restore the equality. If, on the other hand, the projected rate of profit increases falls below the opportunity cost of capital, then producers should boost their production and invest the proceeds of their sales to earn $\delta$ until $\delta$ and market prices drop and Hotelling's Rule holds once more.

Therefore, governments that elect to sell oil and invest the proceeds in SWFs must generate returns that are equal to or greater than the expected rate of unit profit increases of the oil. That rate of profit increases is the opportunity cost that SWFs face, and if the rate of return they earn does not exceed it, then citizens would be 
better served by leaving the oil in the ground for extraction and sale in the future such that the Hotelling equilibrium condition holds.

Historically, how have oil profits fared relative to alternative investments? The chart below illustrates the relative performances of oil and other asset classes from 1985 through 2007.8 Over that time period the rate of increase in the price of oil has significantly lagged the rates of return to most other asset classes, including other commodities. It is worth mentioning that the data tracks changes in the priœ of oil, and that growth of unit profits were likely somewhat greater as the costs of extraction decreased over that time period. Nevertheless, the comparison suggests that SWFs that diversified a country's wealth by investing in a variety of assets offered an attractive alternative to keeping a country's wealth in oil reserves over the past two decades, even though that trend has reversed somewhat since 2004 with the recent spike in oil prices.

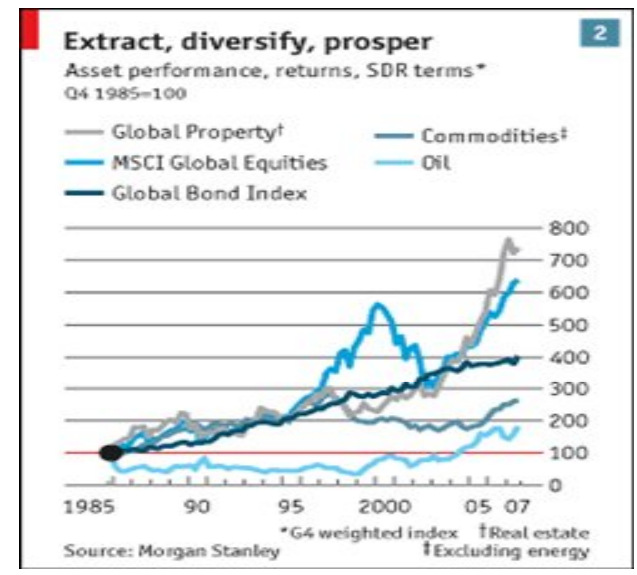

The latest projections of world oil prices suggest that SWFs will continue to offer attractive alternatives to keeping a country's wealth in oil reserves. The Energy Information Administration forecasted in its 2007 Annual Energy Outlook that the real world price of low sulfur light crude will decrease at a compound annual growth rate of $-0.58 \%$ from 2008 through 2030 . In fact, even under the high oil price scenario of its projections where few alternative energy sources become commercially viable and oil production costs increase, real oil prices are still only forecasted to increase at a compound annual rate of $1.78 \%$ through 2030.9 That represents a fairly low hurdle rate for SWFs to meet in order to justify the decision to increase output today and invest the proceeds in other assets when considering, for example, that over the ten-year period from 1997 to 2006 Norway's Government Pension Fund - Global grew at an average real annual growth rate of $4.6 \%$, net of management fees. ${ }^{10}$ Given the additional benefits of diversification and lower variability of returns that SWFs offer over oil, the creation of SWFs seems quite sensible relative the first alternative we have considered - keeping a country's wealth in its oil reserves.

\footnotetext{
8 "Asset-backed insecurity" The E onomist (17 Jan 2008) 79

9 “Annual Energy Outlook 2007” Energy Information Administration, U.S. Department of Energy, February 2007 DOE/EIA0383(2007) Appendix C

${ }^{10}$ Norges Bank Investment Management. Annual Report 2006; Key Figures 2006. http://www.norgesbank.no
} 
EIA World Crude Oil Price Projections 2008 - 2030 (2005 Dollars)

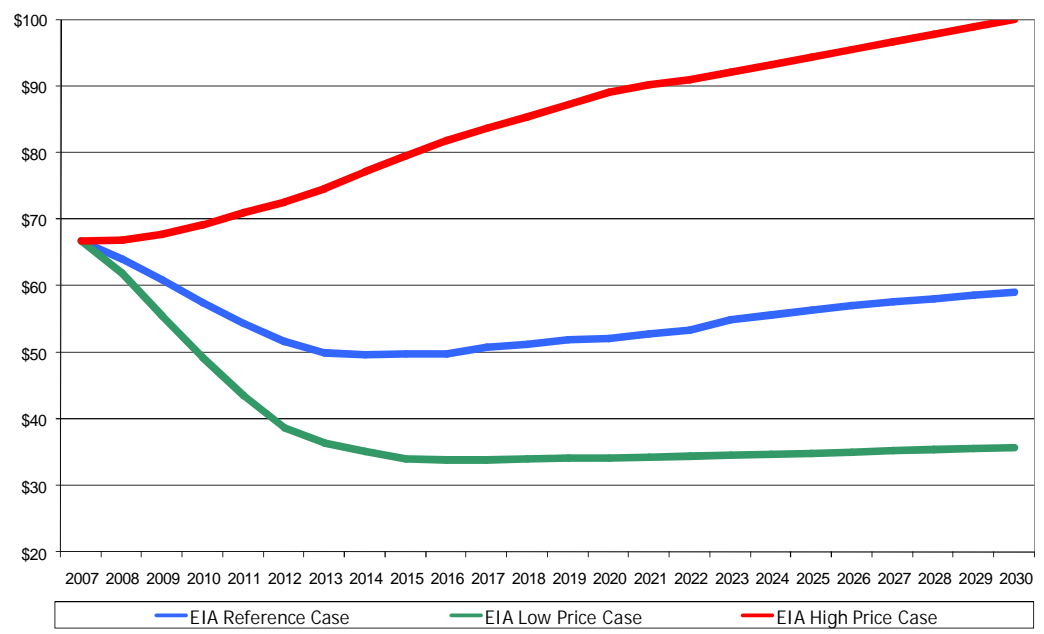

GENERATING INVESTMENT RETURNS: PUBLIC SECTOR VS. PRIVATE SECTOR

Once the decision is made by a government to diversify its holdings away from oil reserves (in the case of oil exporting countries) or the highly liquid and low risk securities kept in a country's foreign exchange reserves (in the case of non-commodity exporting countries), the next option that must be weighed is a private sector alternative to a SWF. The variety of governance structures adopted by different SWFs as well as the unique political and economic backdrop in each country necessitates a case by case approach to evaluating the relative advantages of public and private savings vehicles.

In some countries the returns that individuals can earn on their savings are limited by internal barriers to investment or by cultural factors. In China, for example, investments in the Hong Kong and the London markets have only recently become available to private citizens through brokerages, and regulations on banks limit the investment vehicles offered to citizens. ${ }^{11}$ In Russia, there is a lack of trust in the financial sector by citizens due to the financial crisis in the 1990's and corruption, which serve as barriers to internal investment. Large accounts of corruption, in the forms of bribes and inconsistent enforcement of regulations, have led approximately one third of the population to keep savings in cash rather than trust their money with financial institutions. This results in roughly one quarter of total income being held in dollars rather than invested or held in savings accounts. ${ }^{12}$ To the extent that SWFs can leverage their access to global financial markets and a wider variety of securities to earn higher returns, such as in hedge funds and private equity shares that are largely unavailable to individuals, they can provide an incremental benefit to their citizens. High barriers to private investment indicate that government can obtain higher returns than citizens, therefore we assign a positive value to having the SWF. Low barriers to private investment indicate that citizens can obtain equal or higher returns than government, therefore we assign a negative value to having the SWF.

11 "Chinese Citizens Allowed to Invest in London Stock Market Through Commercial Banks" InsuranceNewsNet.com www.insurancenews.net

12 Gustafson, Thane. Capitalism Russian-Style, Cambridge, UK: Cambridge University Press, 1999. 
Transparency of the fund is a critical factor to determining the effectiveness of private versus public management of the SWF surpluses. Minimal financial reporting requirements or porous insulation from political pressure and access can lower SWF returns relative to private investment vehicles are proxies for transparency of the fund. For example, the transparency of the Abu Dhabi Investment Authority is very low - it has never once revealed the value of its assets under management in its thirty-year history. ${ }^{13}$ Such opaque governance lowers expected returns for two reasons: first, it facilitates mismanagement, and second, it provokes protectionism by recipient countries which limits the funds' investment options. High transparency indicates that government is likely acting in the best interests of citizens and maximizing expected returns, therefore we assign a positive value to having the SWF. Low transparency indicates that government is likely not acting in the best interests of citizens and earning lower expected returns, therefore we assign a negative value to having the SWF.

SWFs susceptibility to corruption and mismanagement also lowers their expected returns relative to private investments in some instances. For example, the regulations of Russia's Stabilization Fund stipulate that the government can tap up to $\$ 18$ billion dollars out of the fund at any time for discretionary spending. This unpredictable access leads to uncertainty about the funds available for investment and also increases the likelihood of corruption and wastefulness. Low evidence of corruption indicates that government is likely acting in the best interests of citizens and maximizing expected returns, therefore we assign a positive value to having the SWF. High evidence of corruption indicates that government is likely not acting in the best interests of citizens and earning lower expected returns, therefore we assign a negative value to having the SWF. As mentioned, all three of these factors are country-specific and will be explored in further depth as they relate to each of the six largest SWFs later in the paper.

There are also some universal factors that influence the net returns of private savings and SWFs. For instance, under current US tax law, sovereign immunity exempts SWFs from paying taxes on portfolio investments in the US, while private foreign citizens and corporations pay tax rates as high as $30 \% .{ }^{14}$ Although most capital gains by foreign entities are viewed as foreign source income and therefore exempt from tax, the difference in tax treatment does exist in most instances for interest and dividend income. This difference can produce significant advantages for SWFs in after-tax returns, particularly in debt instruments. The sheer size of SWFs can also enable them to negotiate substantially lower management fees than individuals are typically charged. For example, Norway's Government Pension Fund paid average management fees of merely $0.1 \%$ over the ten-year period $1997-2006 .{ }^{15}$

\section{POLITICAL IMPLICATIONS}

One of the four factors that determine whether a SWF benefits it citizen is politics. This issue has received a lot of media attention recently but some of the issues raised are not relevant to this paper; for example, the citizens of China are largely unconcerned with liquidity crises here in America, unless there is some indirect costs to them of such crises. However, if SWFs are used to increase the national power of a government, this may be in the citizens' best interests. Just like the other factors, the political factor of a SWF depends heavily on the circumstances of that nation. This section outlines three major themes in the political nature of SWFs:

\footnotetext{
${ }^{13}$ Lyons, Gerald. "State Capitalism: The Rise of Sovereign Wealth Funds." Standard Chartered Bank publication (19 Oct 2007$): 32$

${ }^{14}$ Fleischer, Victor “Taxing Sovereign Wealth Funds”, C onglomerate 4 March 2008; http://www.theconglomerate.org/2008/03/taxingsovereig.html

${ }^{15}$ Norges Bank Investment Management. Annual Report 2006; Key Figures 2006. http://www.norges

bank.no/Pages/Report 65335.aspx
} 
government intervention due to market inefficiency, international political economy, and internal politics. Lastly, this section concludes with a brief discussion of potential political costs.

\section{Government Intervention due to Market Inefficiency}

Liberal economic theory allows government intervention when markets are inefficient. Examples include regulation, anti-trust, and Pigouvian taxes - government uses these devices through the passage of laws and their enforcement. But who passes laws and enforces them internationally? The last half-century has witnessed a remarkable increase in multinational cooperation, treaties, and cooperation. However, all nations subject to such treaties can leave them whenever they so please. Take the Non-Proliferation Treaty as an example - nations can leave the treaty at any time with 90 days notice. United Nations Security Council decisions are only enforced when member nations voluntary enforce them. This lack of international government and therefore lack of international law passage and enforcement is known as the Westphalian paradox - a political theory that states that world power is largely unchanged since the Treaty of Westphalia that defined the nation-state as the highest form of sovereignty. ${ }^{16}$ Taken further, the Westphalian paradox means that nations must act on their own behalf internationally and achieving their interests outside of their borders is largely determined by their relative political power, coercive powers, and bargaining power.

The Westphalian paradox creates challenges with many global problems - global warming, security, international criminal courts, and non-proliferation among many. Another less publicized reason is the lack of international competitive standards or anti-trust. More specifically, there is no standard for government intervention into international markets dominated by monopoly or collusion. One way nations can prevent this is through their own domestic anti-trust legislation. For example, the EU placed restrictive covenants on the 2001 merger of Brazilian ore companies CVRD and Caemi. ${ }^{17}$ Another response is "resource nationalism" that some claim is the real objective of many SWFs, especially the East Asian funds. ${ }^{18}$ Resource nationalism involves governments attempting to take control of sources of raw materials outside their borders in an attempt to prevent monopoly or collusion.

This study analyzes each of these problems - monopoly and collusion - to determine whether a SWF might assist governments in worldwide market intervention. To assess the dangers of an international monopoly, the dominant firm model can be applied (see Appendix 2 for the details of the dominant firm model). The dominant firm model proves economically that for most cases of large-scale consolidation, monopoly power is not created until the dominant firm's market share approaches 100\% (depending on the strength of substitutability of firms and consumers). Therefore, government intervention to prevent monopoly would not be a good justification for use of a SWF. Collusion is harder to quantify but historical experience has shown that collusion becomes easier as the number of firms is reduced. Consolidation, therefore, could create an easier environment for collusion. Unlike monopoly pricing, government market intervention to prevent collusion may be a good justification for a SWF.

Before concluding this section, it is important to separate the justification for government intervention versus the justification for using a SWF as a tool of intervention. Even if an international market inefficiency exists, it does not automatically follow that a SWF is the only means with which a nation can intervene. In the book War by Other Means: Economic Espionage in America, John Fialka details President Clinton's use of the U.S. intelligence agencies in certain market interventions. The Commerce Department was charged with running an Economic operations center to which the CIA and others would refer tips they uncovered during

\footnotetext{
${ }^{16}$ B. Landrum, "The Globalization of Justice: The Rome Statute of the International Criminal Court," Sept 2002.

17 R. Lundmark and M. Nilsson, "Recent Mergers in the Iron Ore Industry," Resources Policy, Mar 2003.

${ }^{18}$ Lyons, Gerald. "State Capitalism: The Rise of Sovereign Wealth Funds." Standard Chartered Bank publication (19 Oct 2007$): 9$
} 
security operations about unfair trade, like bribes. Fialka discusses a particular set of cases in the mid-1990s where European bidders were offering kickbacks to Brazilian firms. Clinton made calls to the president of Brazil and convinced him to intervene, eventually causing the U.S. bidders to get the deal. The U.S. was able to intervene due to its relative political power, suggesting that intervention with a SWF may not be necessary if a government has sufficient political power. A SWF should be seen as one of many tools a government has to intervene in the case of international market inefficiencies.

\section{International Political Economy}

Political economy usually refers to the distribution of wealth among interest groups. Liberal economics is concerned with how wealth is created where political economy is concerned with how wealth is distributed. In the global economy, nations acts like interest groups - bargaining for national shares of global wealth. This is international political economy. There are two main themes of international political economy that affect whether a SWF benefits its citizens: 1) SWFs as an element of national industrial policy and 2) SWFs as a deterrent to protectionism.

First, the theory of international political economy has given rise to the use of industrial policies by nations. Such industrial policies are grounded in what is perceived to be a difference between the logic of the market and the logic of the state. The logic of the market is to locate economic activities where they are most efficient and profitable. Under an industrial policy, the logic of the state is to capture and control the process of economic growth and capital accumulation in order to increase the power and economic wealth of the nation. In this regard, a SWF is seen as an aspect of such an industrial policy. If industrial policies increase the economic wealth of a nation, then its citizens would be better off. Industrial policies involve three main elements: government definition of what industries are important, government subsidization and funding of research for such industries, and protection of industries from foreign competition. The question that arises in attempting to determine the value of an industrial policy is: do the logic of the market and the logic of the state complement one another? Can the state capture the process of economic growth without adversely influencing its location in the most efficient sectors? To answer this question, consider the following chart: ${ }^{19}$

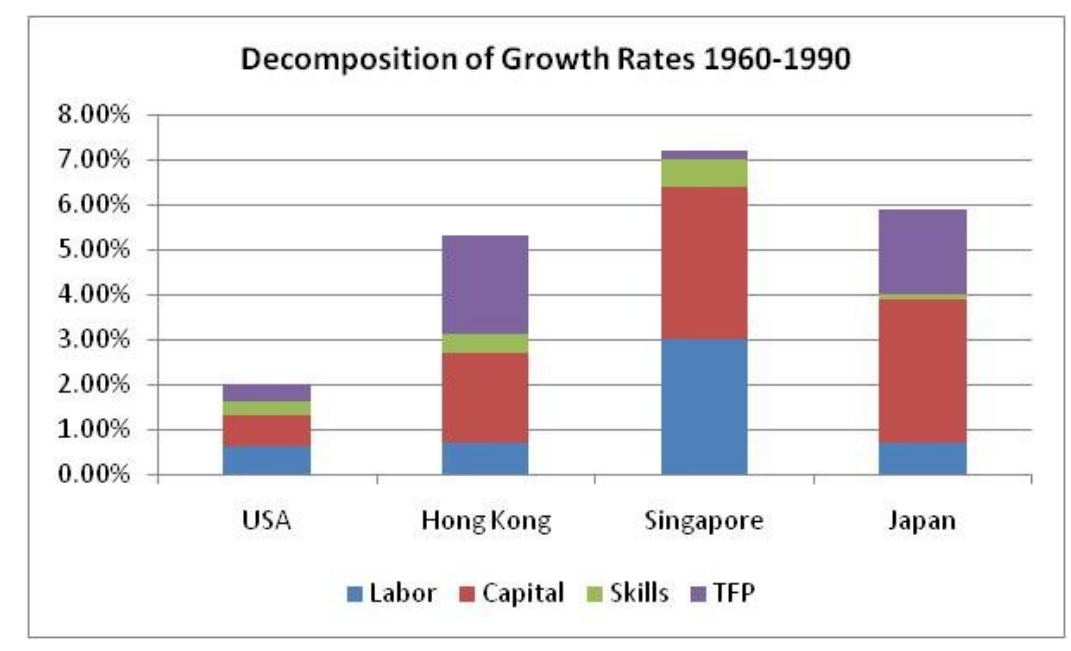

During 1960-1990, Singapore and Japan pursued industrial policies whereas Hong Kong did not. The U.S. is shown for comparison. The growth of Hong Kong, Singapore, and Japan are similar but the sources of their

${ }^{19}$ Data in chart taken from: A. Young, "Lessons from the East Asian NICs: A Contrarian View" and "The Tyranny of Numbers" NBER Working Papers 4482 and 4680, 1993/1994. 
growth are not. Where a significant portion of the growth of Hong Kong and Japan can be attributed to growth in productivity, Singapore's growth appears to have mainly come from increases in factors of production. Between these three nations, there does not appear to be a clear relationship between sources of growth and the existence of an industrial policy. Therefore, in this study, a SWF as an element of a industrial policy provides no clear benefit to its citizens.

There is a second element of international political economy that could influence the choice of a SWF: deterring protectionism. International trade depends on mutual dependence but such dependence may not be symmetrical. Certain nations' economies are more dependent on others, such as export-driven economies. Just as the Westphalian paradox creates an environment where nations have no control over collusion outside of their borders, nations have limited power to prevent the rolling back of free trade agreements. With the current stalemate over the Doha Round of trade negotiations, regional and bilateral free trade agreements have become more popular. However, such agreements are more easily scaled back than global agreements. For example, when the U.S. imposed tariffs on steel in 2002, the WTO ruled against the U.S. allowing the EU to install retaliatory tariffs. However, who would come to the aid of Singapore in the event of U.S. protectionist sentiment that threatened to roll back their bilateral free trade agreement? Singaporean firms have made substantial investments based on this agreement. The current free trade environment creates a higher degree of vulnerability for export-driven economies, many of which have low relative political power compared with their trading partners. Economic power can be defined as the capacity to interrupt economic relations. A SWF with investments overseas provides a national government with deterrent powers over its trading partners. Clearly, citizens of that nation benefit if their government can act to keep free trade agreements in place.

A SWF can also have a political effect as an alliance-building tool. Singapore's investments in the United States may deter the U.S. from protectionism, but it also acts to strengthen Singapore's alliance with the United States generally. Singapore, the UAE, and Kuwait are nations with low relative political power and surrounded by larger and possibly menacing neighbors. SWF investments overseas help to strengthen alliances with the U.S. and other nations that increases their security.

\section{Internal Politics}

A SWF can also be used as a tool for governments to control the internal politics of a nation. As the following chart shows, many of these funds exist in nations with low scores on both the political rights and civil liberties of its citizens. ${ }^{20}$

${ }^{20}$ B. Davis, "State Funds May Not Bolster Freedoms,” WSJ, 11 Feb 2008, p. A2. 


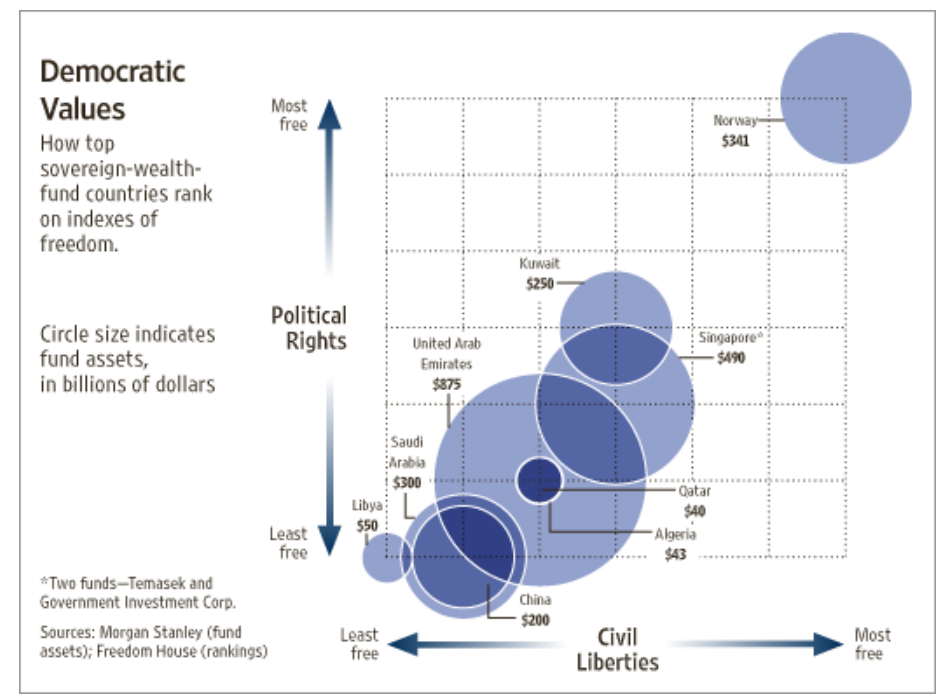

However, there is no clear global consensus on what should come first: greater wealth or greater political freedom. Rapidly modernizing and industrializing nations, such as China, are growing much more rapidly than Western nations ever did. As such, the central government may be justified in maintaining control of certain sectors of the economy. A Chinese government official recently stated that "democracy sacrifices efficiency" in response to detailing how the new terminal at Beijing's airport was designed and built in the same time that it took the British government to conduct an inquiry into the construction of a new terminal at Heathrow. ${ }^{21}$ This came at the expense of 15 villages that were flattened with more than 10,000 residents resettled. China's SWF has been used as a tool to finance these state-controlled ventures. While in the U.S., capitalism and democracy are generally considered complements, some have argued that the method of capital accumulation should be determined by the timing of a nation's economic development. ${ }^{22}$ This theory is used as a justification for the developmental capitalism of Japan and Germany and partial state-controlled modernization of Russia and China. The danger to this is that such financing could simply be traditional political economy transfers to remaining state bureaucrats and communist party officials masquerading as rationales for modernization. This would not benefit citizens. In the 4-Factor model, the utility of shortterm state-control in rapidly modernizing nations is recognized so long as it is seen as temporary, with state control and industrial policies being shed as nations become industrialized. If forced to choose, it seems reasonable for citizens to prefer economic modernization before political liberalization as long as government and citizens' interests converge in the future.

Secondly, a SWF could be used to block Western pressures for further political liberalization or to mute Western criticism of its internal affairs. It is difficult to make any conclusions as to whether a nation's citizens would desire this or not. If citizens do not desire further political liberalization, then this would be a positive; it would be a negative if governments do not represent the desires of its citizens. This is a complex issue and therefore such considerations are not given much weight in evaluating this aspect of the 4-Factor model. However, regardless of the long-term congruence of political aspirations of government and citizens, the potential for balkanization of a nation under rapid democratization is an area that SWFs may provide benefits to citizens. Rapid democratization can sometimes have the effect of removing "the lid" off of a nation that is really not a unified nation - such as in the former Yugoslavia. These transitions can be disastrous to the nation as a whole. Therefore, it may be in the best interests of citizens for this transition to

${ }^{21}$ Economist, "Rushing on by Road, Rail and Air," 16 Feb 2008, p. 31.

22 R. Gilpin, Global Political Economy, 2001, p. 176-7. 
remain stable and peaceful. SWFs are a tool of a national government who can use their funds to make investments in restless regions or regions that become neglected due to rapid modernization.

\section{Potential Costs to political funds}

There are costs to using SWFs as political or social tools. Governments have been poor at picking industrial winners and could also be poor at picking financial winners. In addition to this, many governments where SWFs invest are taking actions that will only add more costs to such uses of sovereign wealth:

- Exon-Florio Act: This provides the President of the United States the authority to halt foreign acquisitions on national security grounds. Legislation such as this prevented the US Dubai ports deal from occurring. Similar legislation exists in other countries, such as Australia.

- Voting rights: In the 2007-2008 sub prime crisis, many financial institutions turned to SWFs for funding. In comparison to other large investors, SWFs were explicitly denied access to board seats. This puts them at a disadvantage when managing their investments, even from a financial perspective

- Potential premium required to invest: There are beginning to be signs that inventors are weary of being involved in a company co-owed by an SWF. As a result, it is possible that SWFs will be limited from owning large percentages of a company (e.g., 9.9\%) and/or even paying a premium to that of other investors. This would depress the financial returns to citizens and potentially limit investment options.

\section{TAXES}

Another alternative use of SWF proceeds is to reduce taxes on its citizens. Taxes are the means by which governments raise revenue. For example, in the United States, this includes social security, payroll, consumption taxes, capital income (capital gains, dividends and interest) and Medicare taxes. As seen below, for the six largest Sovereign Wealth Fund nations, tax revenues as a percentage of GDP varies widely. In order to understand the different options a government has, one must first analyze the impact taxes have on the economy.

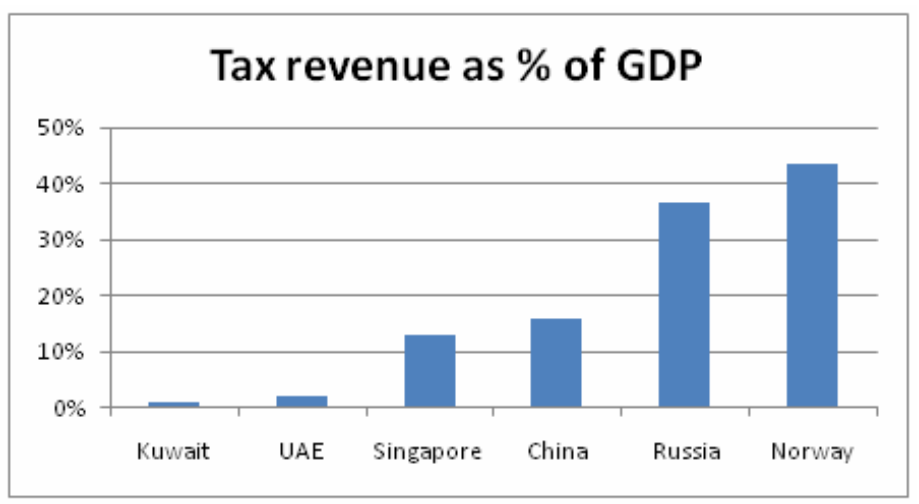




\section{Taxes on the Economy}

Appendix 3 defines the concept of deadweight loss from taxes. Deadweight losses are additional societal losses from taxation - one dollar of taxation results in more than a dollar of loss to society overall. As can be seen in the following chart, changes in the tax amount magnify the deadweight loss exponentially as tax rates go up. More generally, a raise in the tax rate from $31 \%$ to $32 \%$ leads to a far greater deadweight loss than does one from $11 \%$ to $12 \%$.

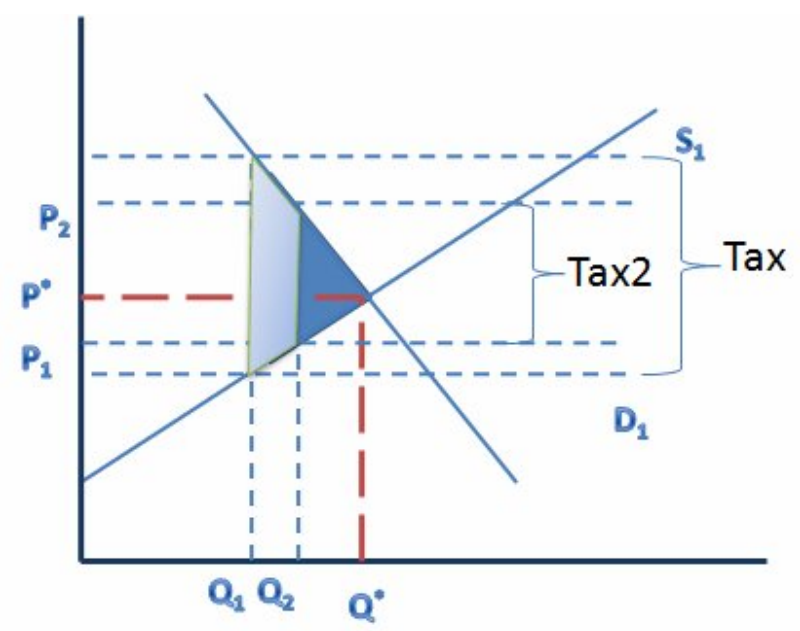

An extension and more intuitive understanding of this important economic concept is called the Marginal Cost of Public Funds (MCPF). Higher tax rates result in a higher cost of raising an additional dollar. The MCPF is: $m=1+E t$ and has two effects: 1) the additional dollar is taken away from social surplus and, 2) $\mathrm{E}$ t, the deadweight loss from raising this dollar of tax revenue (note the DWL increases exponentially with increases in the tax rate). This analysis supports the fact that countries such as Norway, which has a tax rate of $48 \%$ might serve their people more by reducing tax rates. Since Norway already has a high tax rate, a reduction in this tax rate will reduce the DWL and create additional social welfare. This is represented graphically below, where the high tax rate "Tax" is replaced by "Tax 2" resulting in a net decrease in the DWL by the amount shaded in light blue. The OECD reports Norway's MCPF as 1.75 and the U.S. as 1.25

- meaning it costs Norwegian society half a dollar more than U.S. society to raise an additional dollar of tax revenue. Reducing taxes has the opposite effect - giving back a dollar in taxes results in giving back $\$ 1.75$ to Norwegian society.

\section{Taxes and Their Effect on Consumption}

A change in the tax policy will have an impact on consumption and desire to work. In order to analyze this, we first look at the micro-economic view and then analyze the macro-economic view a change in tax policy has on consumption. In order to analyze the benefits of a SWF, we must look at two effects - the substitution effect and the income effect.

\section{Substitution effect (assuming a reduction in taxes):}

1. If taxes decrease, after-tax wages will increase and price of leisure increases.

2. Households will decrease the amount of leisure they consume and increase (substitute towards) the amount of work because leisure is more expensive 
Income effect (assuming a reduction in taxes)

1. If after tax wages increase, households become permanently wealthier, so they consume more goods and leisure.

Impact on consumption (assuming a reduction in taxes)

1. An income tax decrease causes the present value of lifetime resources (PVLR) to increase, so people will increase consumption

2. If leisure becomes more expensive, households will move away from leisure. When income taxes decrease, the substitution effect says households will consume more.

3. It is important to note that a decrease in taxes will have ambiguous effect on desire to work, depending on the size of the income and substitution effects. However, consumption will increase regardless of either effect.

4. The increase in consumption depends on several factors including: whether the tax cut is temporary or permanent, whether households are permanent income households, or Keynesian households and whether they are liquidity constrained.

A detailed analysis of the income and substitution effects can be found in Appendix 4. Additionally, a macroeconomic analysis of an increase in consumption can be found in Appendix 5.

\section{The Need to Consider Inflationary Effects}

As we described above, an unexpected a large subsidy given to each citizen will have several effects. Consumption will increase and the shift in the demand curve will cause quantity and price to increase. Additionally, given the large outflow of cash to citizens, money supply will increase and inflation may be an undesirable consequence. The impact of spending the SWF funds domestically will have on inflation is the most crucial key in analyzing alternatives to a SWF. For example, if the UAE were to give each citizen $\$ 1,300,000$ the surge in the money supply would cause inflation for all normal goods in the country. This abnormally high inflation would make saving less attractive and increase consumption in the short term accordingly, goods would be more expensive for citizens.

To combat the effects of inflation, the government will need to decrease the money supply. However, as mentioned above, if citizens expect high inflation in their home country, they would be less likely to buy their government bonds. Accordingly, it will be difficult to decrease the money supply and inflation will be tough to combat. Given the size of the SWF relative to GDP - it would be difficult for a country to absorb this excess capital within its own borders. Many of the scenarios cause inflation or other unwanted side effects. Detailed analysis of the effects of inflation is beyond the scope of this paper, but this topic should be considered before implementing a new policy.

\section{INFRASTRUCTURE}

One alternative to keeping wealth in a sovereign wealth fund is to make investments in infrastructure. Projects can include roads, airports, or public parks. Ideally, one would compare the return to infrastructure projects to the returns to holding the assets in a SWF. While this approach makes sense theoretically, the returns to infrastructure can be hard to calculate. The growth of a nation can be observed but it is virtually 
impossible to control for other inputs to growth. However, examining each country by understanding how investment affects their specific factors of production can provide a guide as to whether investing in infrastructure makes sense.

The return to infrastructure investments can be viewed by how they affect the variables in the CobbDouglass production function:

\section{Cobb Douglas Function: $\mathrm{Y}=\mathrm{A} \mathrm{K} \cdot{ }^{3} \mathrm{~N}^{\cdot 7}$}

Infrastructure investments can increase Total Production Function (TFP, or " $\mathrm{A}$ ") of a country. In other words, these investments improve the ability of the country to effectively utilize workers/labor ("N") and capital ("K") to raise output ("Y"). Alternatively, infrastructure investments can target greater uses of K and $\mathrm{N}$. Growth accounting is an attempt to determine how nations grow through these options/factors. Two bodies of research provide guidance: the work of Robert Solow and Alwyn Young. A pioneer in growth accounting, Robert Solow showed that America's growth in the early part of this century was mainly due to increases in TFP (represented as A in the Cobb-Douglas function). ${ }^{23}$

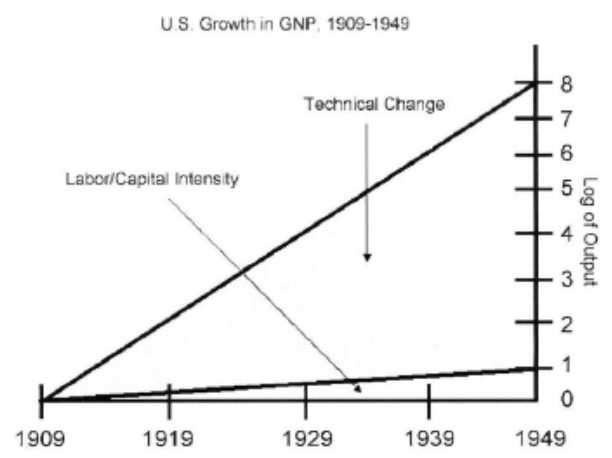

However, in the 1970s, Alwyn Young looked more closely at the growth of the East Asian "tigers" (also discussed in the Politics factor section - see chart labeled Decomposition of Growth Rates). Young's decomposition shows that most of the growth in the East Asian tiger states was due to "catching up" increases in capital and labor - and not due to increases in TFP. TFP growth in rapidly developing countries is simply duplication of existing technology whereas growth in developed nations such as the U.S. comes from new methods of production. Accordingly, nations not on the production frontier should focus their efforts on "catching up." As the following graph shows, many countries with sovereign wealth funds are not on the efficiency frontier.

${ }^{23}$ R. Solow, A Contribution to the Theory of Economic Growth, 1956 and T. Barnett, "Maximizing Welfare Through Technological Innovation," DOJ speech at George Mason University, 31 Oct 2007. 


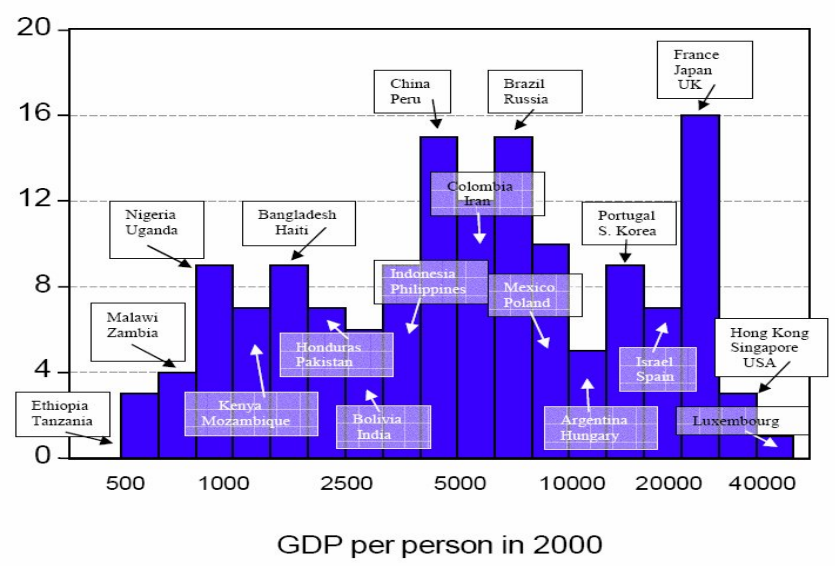

Source: Barro, 2003. Horizontal axis is a log scale. All data are in 1995 U.S. dollars

For example, Singapore is much closer to the frontier than China meaning that Chinese investments in infrastructure would have a higher return than Singaporean investments in infrastructure (e.g., catching up). Improved roads and airports can improve trade between manufacturing-based provinces that are separated by large distances, such as in China and Russia. Take the case of U.S. investment in a system of interstate highways. China is completing its expressway system modeled on the U.S. one. One study showed that for every $\$ 1$ invested in U.S. transportation systems, firms in 35 industries realized a $24 \%$ cost savings in transportation costs. Another study showed both substantial TFP gains in the U.S. economy in the 1950s (31\% of TFP growth during that period) and marginal returns to the highway system ( $25 \%$ of TFP growth in the $1960 \mathrm{~s}$ and $7 \%$ in the 1980s). ${ }^{24}$ There have also been studies that dispute these effects illustrating the difficulties to assessing such projects.

Solow and Young focused heavily on so-called manufacturing nations, but commodity states such as the UAE and Kuwait require a little further discussion. These countries have recently spent large sums of money on projects intended to 1) provide higher leisure to its citizens, and 2) to attract foreign firms and workers. There are a few main points of difference here. First, in these nations where most citizens are wealthy, infrastructure investments that increase the value of leisure make sense. Some public projects, like parks or museums, are investments that private citizens would not make on their own since they are public goods. Such countries are attempting to create a "cluster effect" - making investments to attract firms to their cluster.

\section{Case for Government-Sponsored Investment}

A stated goal of many sovereign wealth funds is to ensure a generational transfer of wealth. Instead of a cash bequest, current generations may desire to transfer a more technologically advanced society, a greater diversified economy, or better public works. Many times, government involvement in infrastructure projects is demanded because of the public-goods nature of them, but government involvement does not necessarily mean public finance.

In determining whether public finance with funds from a SWF are in the best interests of citizens, it can be useful to determine if public finance is cheaper than private finance. Ken Arrow and R.C. Lind have made the case that it is. In corporate finance, the risk of the project is key to determining its cost. According to the

${ }^{24}$ Economist., “America’s Splurge,” 16 Feb 2008, p. 32. 
Arrow-Lind argument, public finance appears to be cheap because the risk is borne by future taxpayers, e.g.. if a government project takes a loss, then they can increase taxes or dip into the SWF. However, they make the case that the risk of a publicly financed project is not necessarily the same as an identical project financed privately. Government projects bear less risk for two main reasons: risk pooling and risk spreading. Risk pooling by the government results in a truly risk-free discount rate reflecting the risk-neutrality of government. However, because private investors can also pool risk, they find the effects of government risk pooling to be minimal. Arrow and Lind point to the stronger case of risk spreading: because the government can spread risk out among the entire tax base, idiosyncratic risk is reduced as far as it can be. ${ }^{25}$ This ArrowLind rule of public finance work has influenced government spending for decades. The 1970 Arrow-Lind rule only includes risk spreading across the current tax base, but in 1996 Michael Klein added to the debate saying that risk spreading is even more significant if governments can spread risk across future generations. ${ }^{26}$ SWFs would seem to be ideal vehicles for generational risk-spreading. One of the arguments against this is that governments may not be trusted as stewards of citizens wealth. However, Arrow and Lind note that although private trusts can also pool and spread risk, individuals are often just as wary of trustees.

\section{Case for Private-Sector Infrastructure}

Private management of projects is often less wasteful and more efficient than government projects. If the costs of government mismanagement exceed the benefits of public finance, then the case for private management of projects is strong. As an extreme example, consider the case of the Brunei Investment Agency (BIA) - the country's SWF - formerly run by the infamous Prince Jefri. The Prince has said that BIA invested in infrastructure; consider some of its recent infrastructure projects: ${ }^{27}$

- $\$ 475 \mathrm{M}$ on Rolls Royce cars and a fleet of 1700 luxury cars

- $\$ 900 \mathrm{M}$ at British jeweler Asprey including five rare diamonds valued at $\$ 200 \mathrm{M}$

- An 180-ft yacht, 100+ master paintings by Picasso and Renoir, and many international hotels

- $\$ 1.8 \mathrm{M}$ bonus to his badminton coach

In total, Prince Jefri is accused of wasting $\$ 14.8 \mathrm{~B}$ of BIA funds. While this is an extreme example in one of the world's remaining absolute monarchies, even central bankers in democratic Western states have tended to make poor decisions when exposed to short-tern politics.

Many government officials do not have long-term interests in mind for their citizens, but rather short-term gains, or personal/political favors. This waste can easily exceed any benefits from generational risk-spreading. All of the SWFs (including Norway) are not run independently and are thus subject to wasteful tendencies. Many, like China's, are even run as an arm of the finance ministry.

\section{Case for Minimal or Quasi-Government Intervention}

One of the pitfalls of infrastructure projects is to equate government involvement with public finance. As discussed, the decision to publicly finance a project depends on the benefits of generational risk-spreading versus the costs of governmental inefficient management. However, this is not to say that government should never be involved. Many infrastructure projects are classically public goods with free-rider problems and the inability to exclude non-payers. Second, the coercive powers of the government may be necessary to allow infrastructure to take place - some projects may require eminent domain, although such problems can

${ }^{25}$ K. Arrow and R. Lind, "Uncertainty and the Evaluation of Public Investment Decisions," American Economic Review, 1970.

${ }^{26}$ M. Klein, "Risk, Taxpayers, and the Role of Government in Public and Private Finance," World Bank, 1996.

${ }^{27}$ M. Maremont, "Will the Prince Turn Pauper?” WSJ (1 Mar 2008): A1,6. 
be internalized through defined property rights. The problem is that transaction costs are usually extremely high in such situations so as to prevent a private-sector solution or bargaining (otherwise knows as a Coaseian solution). Therefore, government involvement is necessary in order to achieve an optimal solution. This is not to say, however, that governments should finance the investment.

A privately-run, but government sponsored infrastructure project will often maximize the strengths of the two previous options. One example is where the government underwrites the project by authorizing it, and then if desired, awards/auctions private contracts to build the infrastructure. On initial review, one can envision a moral hazard, whereby government bears all of the risk. Yet if financial risk is shared among the government and private firm, and the financial return of the private firms are acceptable, this hazard can be avoided.

\section{ALTERNATIVES TO SOVEREIGN WEALTH FUNDS}

There are many alternative uses for the large pools of money that have been accumulated by SWFs. In order to establish a complete framework for analyzing SWFs we need to address these alternatives. Some economists have argued that SWFs should give proceeds directly to its citizens. Different programs that have been mentioned include:

- "Voluntary" SWF - where a private citizen decides whether he/she wants to invest in a fund

- A lump sum remitted to citizens - similar to a tax rebate program in the United States.

- Paying a fixed percentage to every generation.

Economists point to the Permanent Income Hypothesis (PIH) established by Milton Friedman, whereby consumers discount their expected (also known as permanent) income over time. A sharp increase in shortterm income will not result in an equally sharp increase in short term consumption. Furthermore, the PIH suggests that people will save windfall gains in proportion to their savings vs consumption utility discussed in earlier sections. Accordingly, consumers should not respond to predictable changes in their income.

In addition to the PIH, we argue that there are certain psychological elements that one needs to consider when analyzing the rate of savings and consumption expected by citizens. The literature on this subject is mixed. On the one hand, Johnson and Parker (2005) show that US citizens spent between $20-40 \%$ of their 2001 tax rebate on nondurable goods in the first three months. Additionally, nearly $2 / 3$ of the rebate was spent cumulatively during the quarter of receipt and the subsequent three months.

Other studies show that citizens do in fact follow the PIH when the funds remitted are large and expected. For example, Hsieh (2005) discusses the State of Alaska Permanent Fund, where since 1982 half of the annual dividend income the state receives from oil royalties is distributed to Alaskan residents each year. He shows that the regular annual payments from the fund have no impact to changes in consumption. Similarly, Browning and Collado (2001) show that seasonal consumption patterns of Spanish households do not differ for households that receive expected bonuses and those that do not. We can extract two different key points from this analysis. First, a larger remittance is more likely to follow the PIH than a smaller remittance. Second, income that is expected and regular is more likely to follow the PIH than one that is not - this is 
similar to a stock that pays a regular dividend (this dividend is expected and discounted appropriately) versus a onetime special dividend (typically stocks will not discount these and decrease sharply on ex dividend day). ${ }^{28}$

The effects of remitting funds directly to citizens are largely uncertain because of the lack of historical examples. Although our Alaska example above describes the patterns of Alaskan citizens and can be thought of as the most comparable example, applying this analysis to other countries needs further discussion. First, Alaska communicates the dispersion of its funds to its citizens in a clear, anticipated and precise manner. For example, after much anticipation of a large refund in 1996, a July $30^{\text {th }}$ article in the local newspaper printed a headline: "Permanent Fund Profits Set Record: '96 Dividend could Reach \$1,100 Mark." Indeed, the 1996 payment was $\$ 1,131$. Second, applying the Alaskan framework does not account for cultural differences that one would expect across different societies. Discussing cultural differences of each country and the expected savings versus consumption characteristics is beyond the scope of this paper but is essential in analyzing the expected effectiveness of a remittance package.

Lastly, Epley and Gneezy (2005) have shown that in the United States the wording of government windfalls impact consumption. More specifically, remittance described as a "bonus" is more readily spent than an equal sum described as a "rebate". This research emphasizes the psychological implications that individual countries will face when establishing a program.

\section{Applicability of Windfall options}

Given the complications of this analysis, no one recipe will suffice for all nations. However, one initial step that we recommend for most countries is to begin a policy similar to the Alaskan Permanent Fund. Specifically we would recommend remitting a certain portion of fund's capital gains to citizens on an annual basis. This policy will have several advantages:

- It will allow the government to view spending patterns and other implications of a windfall.

- In several countries this system will serve as a form of efficient micro lending to the poor.

- It will help add to nationalism and promote a citizen's association with the SWF.

- It will help improve the SWFs reputation in the international scene - since the SWF can now be identified with a county's citizens.

The last two advantages are significant to our analysis because they strengthen the bond between government and citizens. Secondly, any country attempting this strategy must first take several steps to ensure it works correctly. This program can only be successful if the fund is transparent, which will then lead to accurate expectations of an annual remittance. This is an important point because it emphasizes the differences in fund transparency to its implicit investors - citizens - and fund transparency to outside parties such as overseas investors and governments. The communication between the fund and its citizens must increase as the size of the rebates become larger.

To quantify the potential benefits of this idea, if Norway were to earn $8 \%$ on its assets, and distributed only $5 \%$ of this return each citizen would receive over $\$ 350$. The SWF will still keep $95 \%$ of its return, plus the entire principal and each citizen will still receive nearly half of the expected amount US citizens will receive in the 2008 tax rebate. More importantly, this will allow the government to compile the economic actions of its citizens and experiment with the most efficient way to disperse the funds.

${ }^{28}$ Hsieh, Chang-Tai. "Do Consumers react to anticipated Income Changes? Evidence from the Alaska Permanent Fund" E conomic Review. December 2005 


\section{Other small scale alternatives}

As discussed, government projects are often more wasteful and bureaucratic due to their size and complexity. Programs which reward citizens for desired activities can be implemented in several of the SWF countries. One solution, for less developed countries, can be borrowed from Brazil's "Bolsa Familia" program. In this program, households that earn less than 120 reais (\$68) per head per month - are rewarded with 95 (\$50) if their children attend school and take part in government vaccinations. ${ }^{29}$

Most SWF countries have a more developed economy than Brazil, but can still apply similar programs to target any poor segments of their populations. For example, China can reward citizens for certain behaviors and can help lift citizens from poverty levels. Other countries can reward citizens for attending college or help promote other humanitarian causes. In the next section we summarize the beneficial aspects each country has using our four factor criteria.

\section{COUNTRY SPECIFIC ANALYSIS}

This section analyzes each of the top six SWFs through the 4-Factor model. Each nation is analyzed via the 4-Factor model by assessing whether each of the factors results in a benefit to it citizens: investment environment, politics, taxes, and infrastructure. From here, an overall recommendation for each fund is rendered. As a reminder, the following overall framework was used in making the assessments:

\section{SWF Benefit to Citizens =}

\section{(A) $\{$ (Gov Investment > Private Investment $)+($ Political Gain $>$ Financial Cost $)\}$

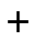

\section{(B) $\{($ SWF $>$ Lowering Taxes $)+($ SWF $>$ Increase Infrastructure Investments $)\}$}

(A) represents positive factors for having a SWF. (B) represents negative factors of a SWF. A positive number for any factor is an argument for keeping the SWF. A negative number for any factor is an argument for eliminating the SWF.

${ }^{29}$ Economist, “Happy Families,” 7 Feb 2008, p. 9-10. 


\begin{tabular}{|c|c|}
\hline Country & UAE \\
\hline Inœeption Year & 1976 \\
\hline Fund(s) & $\begin{array}{l}\text { Abu Dhabi Investment } \\
\text { Authority }\end{array}$ \\
\hline Value (\$B) & 875 \\
\hline CAGR & $10 \%$ \\
\hline Sourœ & Oil \\
\hline Transparency & Very low \\
\hline Fund Value as $\%$ of GDP & $521 \%$ \\
\hline Per capita GDP(\$) & 49,700 \\
\hline Avg. Income (\$) & 16,471 \\
\hline Tax revenue as $\%$ of GDP & $2.10 \%$ \\
\hline Gov't spendingas $\%$ of GDP & $25.70 \%$ \\
\hline Inflation & $9.10 \%$ \\
\hline
\end{tabular}

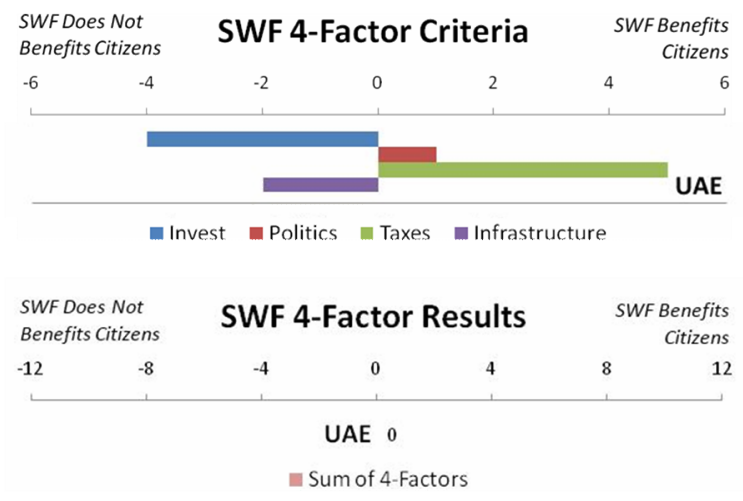

Summary (Overall Score $=0$ )

Investment Environment (Score $=$ - 3)

- The UAE scored a 62.8\% on Heritage International's 2008 Index of Economic Freedom, putting it in the category of Mostly Free nations. ${ }^{30}$ We believe that low barriers to investment allow citizens to generate equal returns as the government. Some evidence of corruption at local and national levels exist, however specific instances of financial mismanagement have not been found. The historically low transparency of the fund also leads us to heavily penalize the UAE on the investment environment dimension.

- Barriers to Investment: Although there are high barriers to foreign direct investment, there exist fairly low barriers to investment from the perspective of private citizens. The 4.5 million citizens of the UAE have access to foreign exchanges and similar investment opportunity sets as the government.

- Government Corruption/Mismanagement: The UAE ranks 31st out of 163 countries in Transparency International's Corruption Perceptions Index for 2006. Widespread corruption has been cited in local governments, however no specific instances of management of investment funds has been cited.

- Transparency: The UAE is one of the worst SWFs on the transparency dimension. ${ }^{31}$ Very little is known about the investment strategy of this fund and their expected returns. A quick look of the Abu Dhabi Investment Authority website (www.adia.ae) showcases how little is known about the actions of this fund.

\section{Politics $($ Score $=+1)$}

- Politics does not appear to be a big factor in the reason for UAE's SWF. However, the UAE SWF does provide one main political benefit to its citizens. The UAE is a small, wealthy nation surrounded by nations with large militaries, a history of aggression, and aspiring nuclear weapons programs. The UAE is culturally different than the U.S. but is also culturally different than its neighboring Arab states as well. The UAE SWFs investments overseas act as an alliance-building political tool enhancing its security and providing a minor benefit to its citizens.

\footnotetext{
${ }^{30}$ Heritage International's 2008 Index of Economic Freedom

${ }^{31}$ Lyons, Gerald. "State Capitalism: The Rise of Sovereign Wealth Funds." Standard Chartered Bank publication (19 Oct 2007$): 20$
} 


\section{Taxes $($ Score $=+5)$}

- The tax environment in the UAE is very beneficial to citizens. Mainly, the UAE has no income tax and no federal-level corporate tax - tax revenue as a percentage of GDP for the UAE was only $2.1 \%$ in 2006. Therefore, a reduction in taxes is not a real alternative for the UAE.

Infrastructure (Score $=-2)$

- The UAE is not yet on the production frontier in many sectors of the economy (non-oil), has incredibly large wealth on a per-citizen basis $(\$ 1.273 \mathrm{~mm})$.

- The UAE has a tiny population and thus could not benefit much from risk-spreading.

- Dubai, in particular, seems intent on becoming the next global financial center (cluster effect), mainly by attracting Western firms and talent. Seen this way, large infrastructure investments can assist in attracting these non-domestic factors of production. This is beneficial to the UAE since taxes are levied on foreign workers and because foreign firms allow its citizens to partner with new businesses outside of oil.

- A current example of infrastructure in the UAE is a land reclamation project costing over $\$ 10 \mathrm{~B}$. Sand from the Persian Gulf seabed is being reclaimed to make a series of off-shore mini-islands in the shape of a globe. While the government has borne the initial cost, a portion of the investment will be recouped through sales to developers and home buyers. In fact, this reclamation project is the third - the first two created land in the shape of palm trees.

- It should be noted that these shapes are only visible from airliners landing at the airport or from the upper floors of some downtown buildings. This example displays the intricacies of assessing such projects. In the U.S., a publicly financed project expected to take a loss would not be acceptable. However, the Dubai government sees the project operating at a net gain because the project will generate positive externalities by attracting foreign firms, capital, and workers increasing $\mathrm{K}$ and $\mathrm{N}$ in the Cobb-Douglas production function and moving Dubai closer to the production frontier. Future Dubai citizens will be better off by being born into a more modern and diversified economy. The final part of that debate is: would that Dubai grandchild have preferred to receive a remittance rather than a little more modern economy and a little more advanced job market? Unfortunately, the difficulties in assessing the returns to infrastructure projects - even quasi-government ones that maximize the benefits of risk spreading and minimize wasteful costs - require a certain element of qualitative assessment.

- UAE's strategy to make itself into a financial and commercial cluster in the Mideast may work but we assess a negative score for infrastructure due to the marginal returns to further investment. Dubai seems well on the way to becoming a diversified economy in the future. How many more firms will a fourth reclamation project attract? 


\section{SINGAPORE}

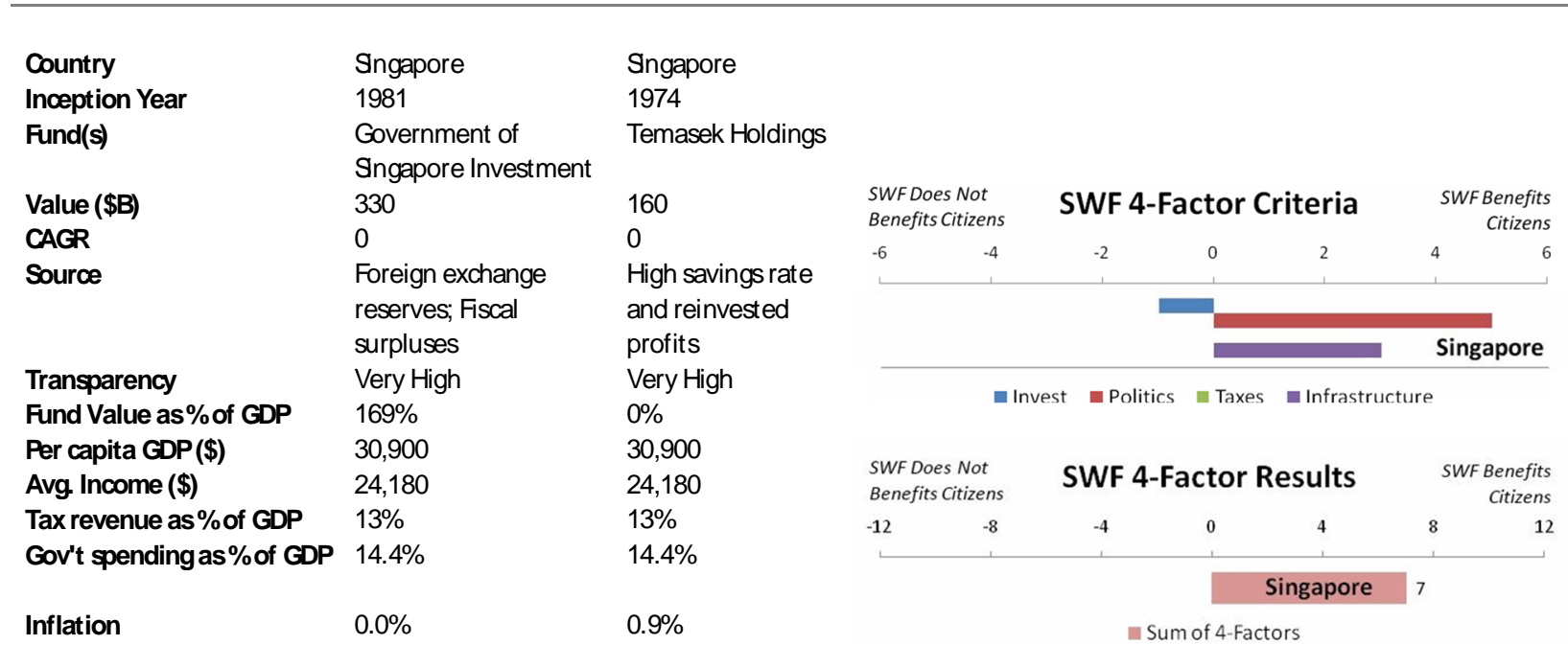

Summary (Overall Score $=+7$ )

Investment Environment (Score = - 1)

- The UAE scored an 87.4\% on Heritage International's 2008 Index of Economic Freedom, putting it in the category of Free nations, the highest rating. ${ }^{32}$ We believe that very low barriers to investment allow citizens to generate equal returns as the government. Little evidence of corruption and financial mismanagement exist. Overall, the low corruption and high transparency make us relatively indifferent to government investment, however the extremely low barriers to private investment weighs our rating slightly towards not having a government managed SWF on the investment environment dimension.

- Barriers to Investment: There are very low barriers to investment from the perspective of private citizens. The citizens of the Singapore have access to foreign exchanges and similar investment opportunity sets as the government.

- Government Corruption/Mismanagement: Singapore ranks 5th out of 163 countries in Transparency International's Corruption Perceptions Index for 2006. ${ }^{33}$ Strong anti-corruption laws are in place and little to no evidence exists of financial management by the government.

- Transparency: Transparency of the Singapore SWF is high. ${ }^{34}$ Again, we combine the Government of Singapore Investment Corporation and the Temasek Holdings funds for the purposes of our analysis. Although the structure and investments of the Government of Singapore Investment Corporation are public, the detailed financial reports are unavailable which lead us to rate the transparency of this fund as medium. Temasek has high transparency as its investments and detailed financial reports are publicly available. Overall, this leads us to rate Singapore's SWF as high.

\section{Politics (Score $=+5)$}

- A SWF provides Singapore with a source of asymmetric national power. Their economy is highly dependent on trade and exports and is particularly vulnerable to its bilateral free trade agreement with the United States. Additionally, Singapore has low relative political power with its trading partners. China also has an export-driven economy but has a seat of the United Nations Security Council. As such,

\footnotetext{
32 Heritage International's 2008 Index of Economic Freedom

${ }^{33}$ Ibid

34 Lyons, Gerald. "State Capitalism: The Rise of Sovereign Wealth Funds.” Standard Chartered Bank publication (19 Oct 2007$): 22$
} 
China can use this political tool as a kind of quid pro quo. Singapore does not have this luxury. However, it should be noted that the deterrent effect of overseas SWF investments is both untested and somewhat weak. If the government of Singapore were to trigger the exit of its SWF investments in the United States, domestic U.S. investors would step in to purchase the exiting positions in a "fire-sale" environment. Furthermore, while this is unlikely to happen in the U.S., any overseas government can simply 'freeze' assets to prevent their exit.

- Singapore SWF investments have the effect on strengthening political alliances with trading partners. While Singapore currently has no clear enemies, it is an island nation surrounded by much larger and historically maritime powers in a region with a quickly changing security environment. Investments in allied Western nations give Singaporean leaders greater political power by strengthening ties with allies that might be needed in the face of future political threats.

- Singapore funds both make a large number of strategic investments. Singapore should pay close attention to the political fallout of such direct investments.

\section{Taxes $($ Score $=0)$}

- A SWF neither benefits nor hurts citizens with respect to taxes. Government expenses and revenues are about equal with tax revenue equal to $12.9 \%$ of GDP while government spending is $14.4 \%$ of GDP. Singapore's income tax rates are relatively low and can be found below:

\begin{tabular}{lr}
$\frac{\text { Income }}{\text { 0- } \$ 20,000}$ & Tax Rate \\
\cline { 2 - 2 }$\$ \$ 20,000-\$ \$ 30,000$ & $0 \%$ \\
$\$ \$ 30,000-\$ \$ 40,000$ & $3.50 \%$ \\
$\$ \$ 40,000-\$ \$ 80,000$ & $5.50 \%$ \\
$\$ \$ 80,000-\$ \$ 160,000$ & $8.50 \%$ \\
$\$ \$ 160,000-\$ \$ 320,000$ & $14 \%$ \\
$\$ \$ 320,000$ and above & $17 \%$ \\
& $20 \% 35$
\end{tabular}

- Singapore's GDP has grown 45\% between 2003 and 2007 because of strong worldwide demand for its exports. Unemployment has fallen to an all time low of $3.1 \%$. Finally, consumer expenditure is roughly $40 \%$ of GDP. Singapore's current marginal tax policy taxes the wealthy more and an consumer spending is still relatively high. Thus, we gave Singapore a 0 score for taxes. ${ }^{36}$

Infrastructure (Score $=+3)$

- Singapore has a small population (4.48mm in 2006) and a small land mass $\left(\left(1 / 13,677\right.\right.$ th of the USA $\left.{ }^{37}\right)$. The small population size means that Singapore cannot benefit greatly from risk spreading.

- The country is close to or on the production frontier, and is the 17 th wealthiest country in the world according to GDP per capita. It has already achieved, for example, the world's busiest port in terms of tonnage shipped, and is the fourth largest foreign exchange center. We conclude that, in general, infrastructure would be a low-return investment for Singapore.

\footnotetext{
35 Heritage International's 2008 Index of Economic Freedom

36 GMID - Global Market Information Database

${ }^{37}$ Statistics Singapore, 2006 of 704 sq-km. Note: The UN official figure from 2004 is 683 sq-km.
} 


\section{NORWAY}

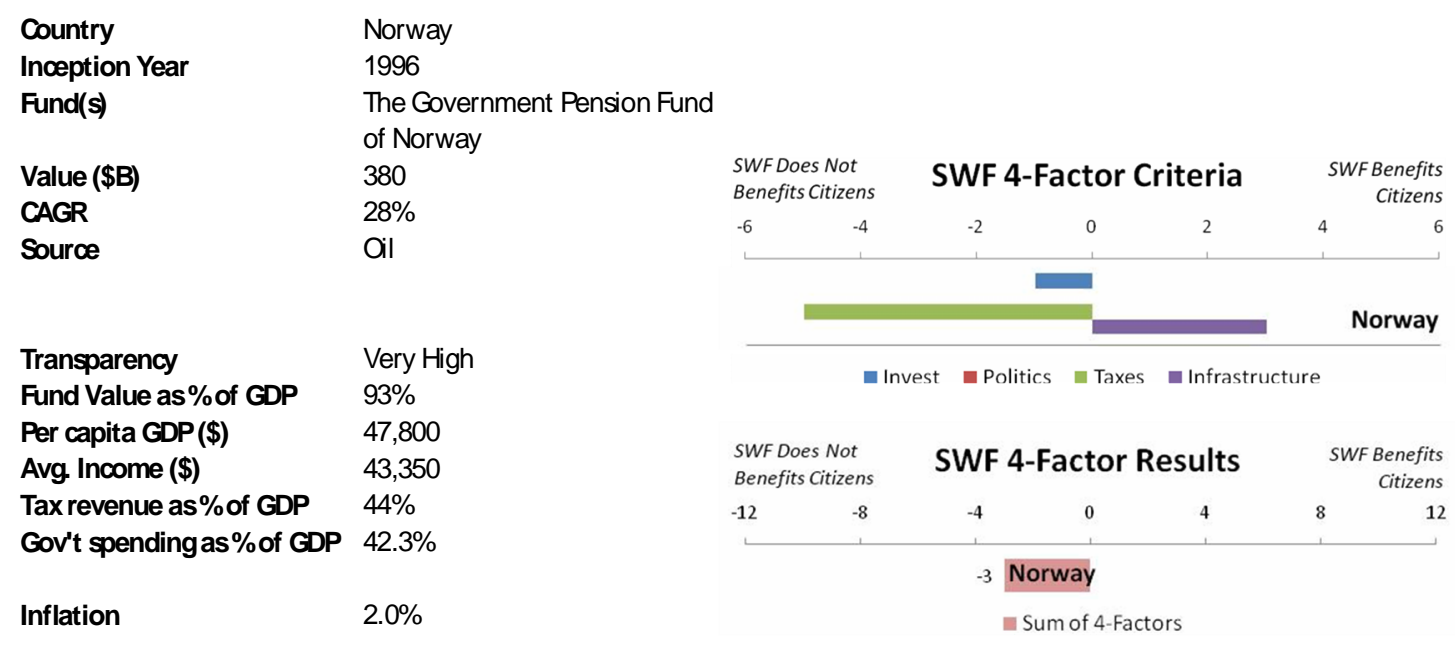

\section{Summary (Overall Score $=-3$ )}

\section{Investment Environment (Score $=$ - 1)}

- Norway scored a 69\% on Heritage International's 2008 Index of Economic Freedom, putting it in the category of Moderately Free..$^{38}$ Although Norway is rated lower than Singapore on this index, we believe this is primarily due to the index's consideration of high taxation. We address the taxation dimension in our 4-factor model. All other things being equal, we see the investment environment of Norway as very similar to Singapore, therefore we rate them equally. We believe that very low barriers to investment allow citizens to generate equal returns as the government. Little evidence of corruption and financial mismanagement exist. The transparency of the fund is high, which weighs us toward being indifferent to the SWF. Overall, the low corruption and high transparency make us relatively indifferent to government investment, however the extremely low barriers to private investment weighs our rating slightly towards not having a government managed SWF on the investment environment dimension.

- Barriers to Investment: There are very low barriers to investment from the perspective of private citizens. The 4.6 million citizens of Norway have access to foreign exchanges and similar investment opportunity sets as the government.

- Government Corruption/Mismanagement: Norway ranks 8th out of 163 countries in Transparency International's Corruption Perceptions Index for 2006. ${ }^{39}$ Strong anti-corruption laws are in place and little to no evidence exists of financial management by the government.

- Transparency: Transparency of the Norway SWF is high. ${ }^{40}$ The structure, investments and detailed financial reports are publicly available which lead us to rate the transparency of Norway's SWF as high.

\section{Politics $($ Score $=0$ )}

- The politics of Norway's SWF does not appear to provide or remove many benefits for its citizens. Norway's political needs are largely met through other means. However, there is one political aspect of the Norwegian fund that could be seen as a negative. The fund has a recent history of divesting from

\footnotetext{
${ }^{38}$ Heritage International's 2008 Index of Economic Freedom

${ }^{39}$ Ibid

${ }^{40}$ Lyons, Gerald. "State Capitalism: The Rise of Sovereign Wealth Funds." Standard Chartered Bank publication (19 Oct 2007$): 21$
} 
investments due to human rights issues (one recent divestiture was from a US company - for human rights reasons). While there is no good information on the financial costs to such actions for the Norwegian Fund, California's pension fund Calpers recently released a memo that detailed the costs of such restrictions - political restrictions cost Calpers $\$ 410 \mathrm{M}$ or $2.6 \%$ in return. ${ }^{41}$ It is hard to say whether the costs of such political statements would be desired by Norwegian citizens. Considering that their government can make political statements in other ways and forums, would they want a higher return instead?

\section{Taxes $($ Score $=-5)$}

- With a top income tax rate of $47.8 \%$ Norway has the highest tax rate of countries examined. Similarly, government spending as a percentage of GDP is high at 43\%. We feel that Norway citizens can benefit enormously with a reduction in the tax rate. This would eliminate current inefficiencies created by a high tax rate. Consumer spending accounts for roughly 1/3 of GDP, while oil and natural gas exploration accounts for nearly $20 \%$ of GDP. 42

- Norway's economy has been one of the world's strongest over the last few decades; however, we feel that greater benefits are possible. An influx in labor from new EU member states has offset the increase in wages one would expect from increased revenues in oil. Higher oil prices have helped fund infrastructure development, and Norway's long term goal should be to limit its dependencies on oil revenue. ${ }^{43}$

- We feel that by decreasing the tax rate the marginal cost of public funds will decrease and citizens' desire to consume leisure will decrease. Thus, individuals will have incentive to work more, and with higher incomes consumption will increase. This will help add to the benefits the Norwegian economy has experienced over the past several decades. Finally, Norway already has nearly $\$ 90,000$ per citizen in the SWF and citizens would prefer a reduction in taxes to accumulation in the fund.

\section{Infrastructure (Score $=+3$ )}

- Norway has the second highest GDP per-capita (after Luxembourg), although the government controls $31.6 \%$ of publicly listed companies. The country also has a small population (under $5 \mathrm{~mm}$ in 2007), which is not ideal for government risk-spreading

- The government has shown commitments to distributing wealth to future generations. Secondly, nonoil/gas exports represented roughly $42 \%$ of the economy.

- Given the above information, we do not believe that massive infrastructure projects would be the highest return given Norway-specific alternatives such as reducing the high tax rate but quasi-government involvement in more advanced infrastructure projects could help to continue to diversify the economy.

\footnotetext{
${ }^{41}$ B. Steil, "California's Sovereign Wealth Fund,” WSJ, 7 March 2008, p. A14.

42 GMID - Global Market Information Database

${ }^{43} \mathrm{Ibid}$
} 


$\begin{array}{ll}\begin{array}{l}\text { Country } \\ \text { Inœption Year } \\ \text { Fund(s) }\end{array} & \begin{array}{l}\text { Kuwait } \\ 1953 \\ \text { Kuwait Investment Authority. } \\ \text { Value (\$B) }\end{array} \\ \begin{array}{l}\text { CAGR } \\ \text { Source }\end{array} & 250 \\ & \begin{array}{l}\text { N/A } \\ \text { Oil. Each year 10\% of } \\ \text { revenues are contributed }\end{array} \\ \text { Transparency } & \text { Low } \\ \text { Fund Value as\% of GDP } & 265 \% \\ \text { Per capita GDP(\$) } & 21,600 \\ \text { Avg. Income (\$) } & 16,340 \\ \text { Tax revenue as\% of GDP } & 1 \% \\ \text { Gov't spendingas\% of GDP } & 29.1 \% \\ \text { Inflation } & 3.1 \%\end{array}$

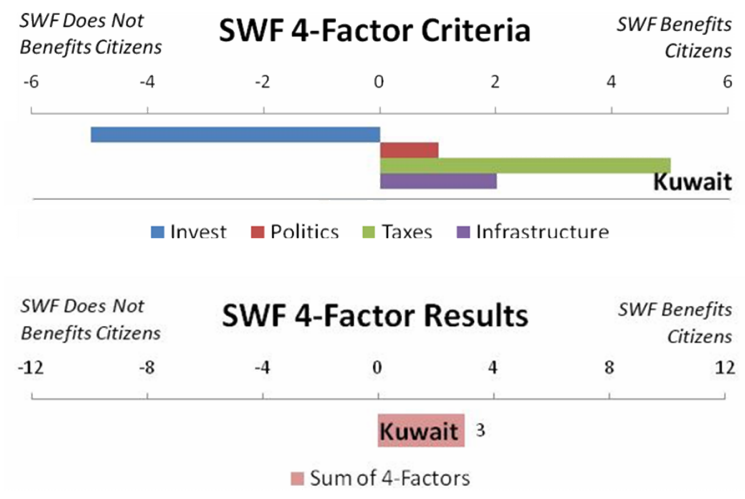

Summary (Overall Score $=+3$ )

Investment Environment (Score $=\mathbf{- 5})$

- Kuwait scored a 68.3\% on Heritage International's 2008 Index of Economic Freedom, putting it in the category of Moderately Free. ${ }^{44}$ We see the investment environment of Kuwait as very similar to the UAE with an even stronger case for private management due to the higher evidence of corruption. We believe that low barriers to investment allow citizens to generate equal returns as the government. Evidence of corruption at local and national levels exist, which lead us to penalize a government managed SWF on this dimension. The historically low transparency of the fund also leads us to heavily penalize the Kuwait on the investment environment dimension.

- Barriers to Investment: There are very low barriers to investment from the perspective of private citizens. The 2.5 million citizens of Kuwait have access to foreign exchanges and similar investment opportunity sets as the government.

- Government Corruption/Mismanagement: Kuwait ranks 46th out of 163 countries in Transparency International's Corruption Perceptions Index for 2006. All branches of the government have been cited for corruption and potential financial mismanagement, leading us to heavily penalize the SWF on this dimension. ${ }^{45}$

- Transparency: Transparency of the Kuwait SWF is low. ${ }^{46}$ The structure, investments and detailed financial reports are unavailable leading us to penalize Kuwait on this dimension.

\section{Politics $($ Score $=+1)$}

- Kuwait is very similar to the UAE and thus has the same political score. It should be noted that Kuwait shares a border and important waterway with Iran and is thus closer to a potential rival. The majority of UAE and Kuwaiti oil is shipped through the Straits of Hormuz. Kuwait knows firsthand what it is like to be a victim of aggression. However, unlike UAE, Kuwait has a substantial foreign military presence on its soil and thus that could easily be seen to supersede the alliance-building power of its SWF.

\footnotetext{
${ }^{44}$ Heritage International's 2008 Index of Economic Freedom

45 Heritage International's 2008 Index of Economic Freedom

${ }^{46}$ Lyons, Gerald. "State Capitalism: The Rise of Sovereign Wealth Funds." Standard Chartered Bank publication (19 Oct 2007$): 23$
} 


\section{Taxes $($ Score $=+5)$}

- Similar to the UAE, Kuwait has no individual tax rate or corporate tax rate for citizens. Foreign owned firms can be subject to a tax rate as high as 55\%. Tax revenue was less than $1 \%$ of GDP for 2006 so there is virtually no room to reduce taxes. Thus, for taxes, Kuwait receives a +5 meaning a SWF greatly benefits citizens. ${ }^{47}$

\section{Infrastructure (Score $=+2)$}

- Kuwait has high GDP per capita (US\$55,300 per person) and recent GDP growth of 5.7\% but their economy is largely undiversified. Petroleum and petrochemicals account for an overwhelming $95 \%$ of exports, and nearly half of GDP. For this reason, we assess a positive score for infrastructure since a government/SWF sponsored investment strategy could encourage the economy to diversify. However, with UAE already on its way to becoming the new commercial center of the region, it is unclear if the region would support another.

- Since the First Gulf War, the Kuwaiti government has spent billions of dollars to construct elaborate roadways and a telecommunications system. However, Kuwait has a very small population $(3.4 \mathrm{~mm}$ as of 2007 ) and it is unclear how a roadway network would vastly improve its economy. In fact, Kuwait needs to guard against making unwise infrastructure investments. Flush with oil money in the 1980s, Saudi Arabia made infrastructure investments such as building the largest working bicycle in the world (200 feet high) and building the massive Hajj terminal to house pilgrims on their way to Mecca. Both projects are impressive symbols of national wealth but do not substantially improve their domestic economy. Kuwaiti grandchildren would probably prefer wealth or a diversified economy over footnotes in the Guinness Book of World Records.

${ }^{47}$ GMID - Global Market Information Database 


\section{CHINA}

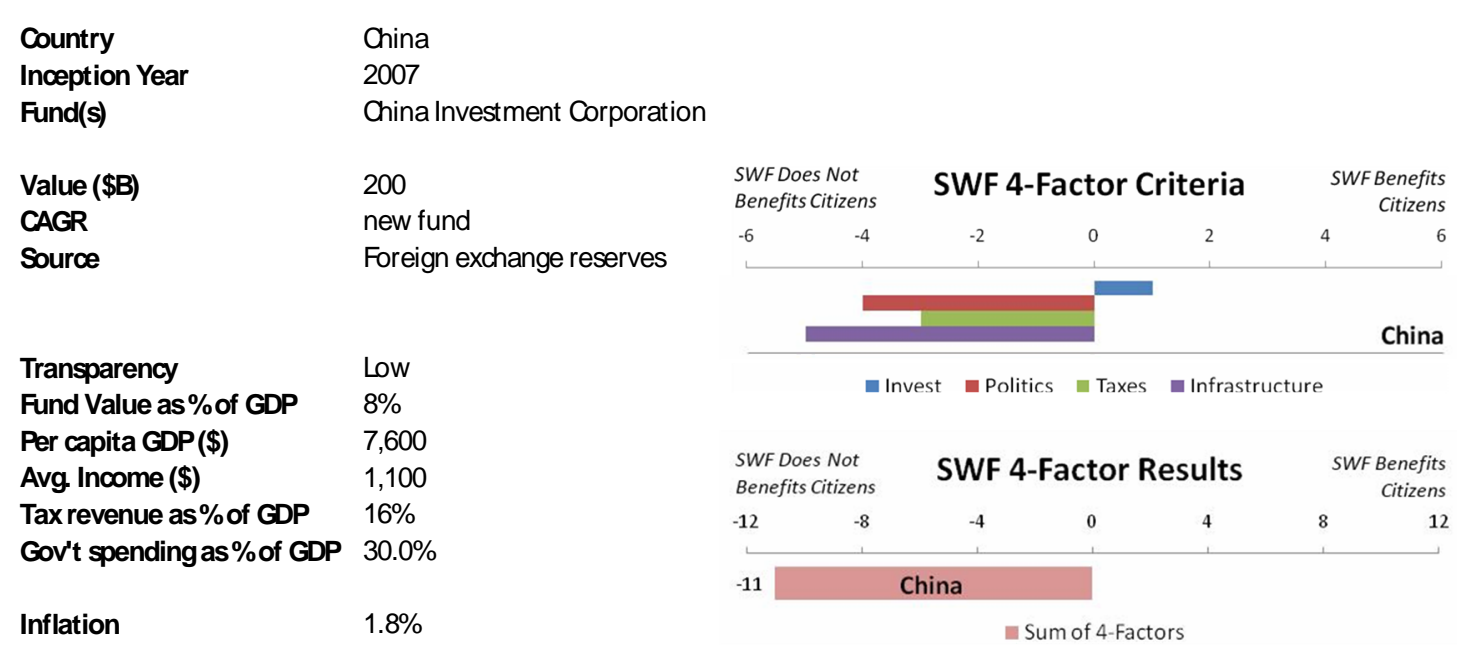

Summary (Overall Score $=-11)$

\section{Investment Environment (Score $=+1)$}

- China scored a 52.8\% on Heritage International's 2008 Index of Economic Freedom, putting it in the category of Mostly Unfree. ${ }^{48}$ We see the investment environment of China as very similar to Russia with a slightly weaker case for government management due to a lower level of transparency. We believe that high barriers to investment preclude citizens from generating equal returns as the government. Significant evidence of corruption at local and national levels exist, which lead us to penalize a government managed SWF on this dimension. The historically low transparency of the fund also leads us to heavily penalize the China fund on the investment environment dimension. Although we penalize the fund for high corruption and low transparency, we weigh heavily on the current restrictions to private investment which lead to lean slightly towards government management of the fund to generate higher returns.

- Barriers to Investment: There are significant controls on investment by the citizen, with private access to only two foreign exchange markets. ${ }^{49}$ The 1.3 billion citizens of China are extremely regulated in their banking and investment activities, leading us to favor government management to generate higher returns.

- Government Corruption/Mismanagement: China ranks 70th out of 163 countries in Transparency International's Corruption Perceptions Index for 2006. All branches of the government have been cited for corruption and potential financial mismanagement, leading us to heavily penalize the SWF on this dimension. ${ }^{50}$

- Transparency: Transparency of the Chinese SWF is low. ${ }^{51}$ The structure, investments and detailed financial reports are unavailable leading us to penalize China on this dimension.

\section{Politics $($ Score $=-4)$}

- The Chinese SWF has stated that "political and social returns" are part of its fund's objectives.

\footnotetext{
${ }^{48}$ Heritage International's 2008 Index of Economic Freedom

${ }^{49} \mathrm{Ibid}$

${ }^{50} \mathrm{Ibid}$

${ }^{51}$ Lyons, Gerald. "State Capitalism: The Rise of Sovereign Wealth Funds." Standard Chartered Bank publication (19 Oct 2007$): 24$
} 
- Officials of the China Development Bank have expressed concern over the proposed Rio Tinto-BHP merger in the iron ore industry, arguing that consolidation will result in higher prices for Chinese firms and citizens. Furthermore, the SWF has funded an unsolicited bid by China's state-owned mining corporation in what many believe to be an attempt to block the merger. A combined Rio Tinto-BHP would control 32\% of iron ore globally. As shown in Appendix 6, such a consolidation would not result in monopoly power, even using short-term estimates of demand and supply elasticities. The one threat to Chinese consumers would be to prevent collusion among firms. If this is their reason for intervening - and not to prevent monopoly pricing - then intervention could be justified.

- China has an export-driven economy and is dependent on free-trade policies remaining in place. However, China does not depend heavily on bilateral free trade agreements and has substantial political power. China could easily intervene much as U.S. Presidents do - by simply calling on national leaders to change their policies. They have a seat of the United Nations Security Council and are increasingly involved in other regional and international organizations. It is not clear what extra power a SWF gives their government.

- China has a long history of political upheaval caused by differential wealth creation in rival provinces. A SWF may provide the national government with a tool to make investments in far-flung regions neglected by the emerging Chinese private sector. However, only a small portion of their SWF wealth is being used to this aim - most funds are invested overseas in the U.S. or used to finance state-controlled firm investment in places like the Congo.

\section{Taxes $($ Score $=-3)$}

- With a top income tax rate of $45 \%$ and a top corporate tax rate of $33 \%$, China has is an interesting example. In 2006, overall tax revenue as a percentage of GDP was $15.8 \%$ while overall government spending was $30 \%$ of GDP. Consumer expenditures are roughly $37 \%$ of GDP. Thus, the government uses the proceeds of state owned businesses to fund its expenses. Officially, the government is trying to alter their growth model. On the demand side, China would like to be less dependent on exports. On the supply side, the country would like to shift to more of a service provider. ${ }^{52}$

- China has experienced remarkable growth over the past 50 years; the percentage of the population living on less than $\$ 1$ / day decreasing from $64 \%$ to $10 \%$ in 2004 . However, income inequality has risen, and is especially apparent in the rural areas. There are still roughly $100 \mathrm{~mm}$ people in China living on less than $\$ 1$ per day. Thus, we feel that Chinese citizens can benefit from a reduction in taxes, and would recommend a tax rebate to all citizens. This rebate will help form a higher PVLR and consumption will increase (we would expect larger percentage increases in consumption from the poor). China has many other options for its capital, and the current SWF structure does not benefit citizens.

\section{Infrastructure (Score $=\mathbf{- 5})$}

- China is largely a manufacturing economy - infrastructure projects have high returns as logistics needs of such industries are assisted. Infrastructure needs in China could easily swallow up their \$200B fund.

- Improved roads/airports can improve trade between the manufacturing-based provinces that are separated by large distances. For example, currently the Chinese rail system only provides for $40 \%$ of desired capacity. Logistics costs in China represent 18\% of GDP versus 10\% in the U.S. China also has $70 \%$ of the world's toll-roads, increasing costs to firms and creating congestion. ${ }^{53}$

- Furthermore, China has the world's largest population, which can support risk spreading. As such, government-funded infrastructure projects might prove useful in adding/attracting factors of production.

\footnotetext{
52 GMID - Global Market Information Database

${ }^{53}$ Economist, "Rushing on by Road, Rail and Air," 16 Feb 2008, p. 29-31.
} 


\section{RUSSIA}

$\begin{array}{ll}\begin{array}{ll}\text { Country } \\ \text { Inœption Year }\end{array} & \text { Russia } \\ \text { Fund(s) } & 2004 \\ & \begin{array}{l}\text { Stabilization Fund of the } \\ \text { Russian Federation }\end{array} \\ \text { Value (\$B) } & 148 \\ \text { CAGR } & \begin{array}{l}\text { doubled since Sept 2006 } \\ \text { oil base level is \$20 - above } \\ \text { which revenue is credited to } \\ \text { this fund. }\end{array} \\ \text { Source } & \text { High } \\ \text { Transparency } & 14 \% \\ \text { Fund Value as\% of GDP } & 12,100 \\ \text { Per capita GDP(\$) } & 8,920 \\ \text { Avg. Income (\$) } & 37 \% \\ \text { Tax revenue as\% of GDP } & 31.9 \% \\ \text { Gov't spending as\% of GDP } & \\ & 12.7 \%\end{array}$

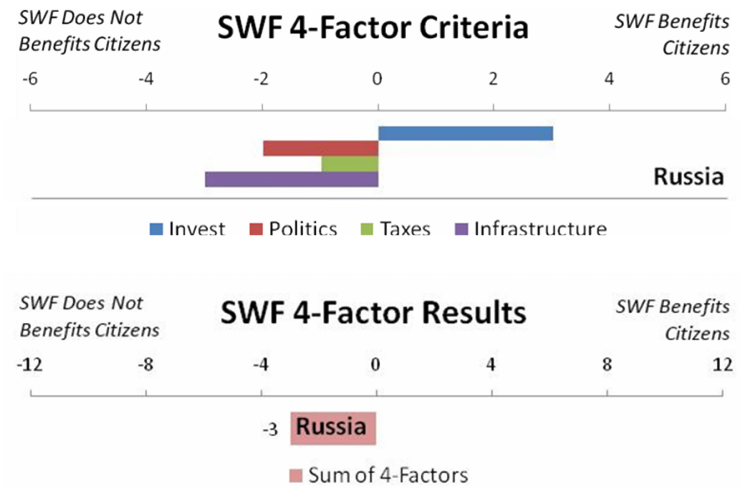

Summary (Overall Score $=-3$ )

Investment Environment (Score $=+3)$

- Russia scored a 49.9\% on Heritage International's 2008 Index of Economic Freedom, putting it in the category of Repressed. ${ }^{54}$ We see the investment environment of Russia as very similar to China with a slightly stronger case for government management due to a higher level of transparency. We believe that very high barriers to investment preclude citizens from generating equal returns as the government. Significant evidence of corruption at local and national levels exist, which lead us to penalize a government managed SWF on this dimension. The historically high transparency of the fund leads us to credit SWF on the investment environment dimension. Overall, we see the high barriers to investment and high transparency as factors outweighing the corruption factor which results in a positive rating for government management on the investment environment dimension.

- Barriers to Investment: There are significant controls on investment by the citizens, with a lack of trust in the financial system often leading citizens to hold more cash versus saving versus saving with banks. ${ }^{5}$ Although the 143 million citizens of Russia have access to foreign exchanges, the undercapitalized financial system and restrictions on some investments lead us to favor government management to generate higher returns.

- Government Corruption/Mismanagement: Russia ranks 121th out of 163 countries in Transparency International's Corruption Perceptions Index for 2006.56 All branches of the government have been cited for corruption. Recent news about embezzlement in the SWF is further evidence of corruption and mismanagement..$^{57}$ All of these factors lead us to heavily penalize the SWF on this dimension.

- Transparency: Transparency of the Russia SWF is high. ${ }^{58}$ The structure, investments and detailed financial reports are available to the public which lead us to credit the Russian SWF on this dimension.

\section{Politics $($ Score $=-2)$}

${ }^{54}$ Heritage International's 2008 Index of Economic Freedom

55 Gustafson, Thane. Capitalism Russian-Style. Cambridge, United Kingdom: Cambridge University Press, 1999.

${ }^{56}$ Heritage International's 2008 Index of Economic Freedom

57 Aslund, Anders. "The Truth About Sovereign Wealth Funds." Foreign Policy. December 2007.1 February 2008. http://www.foreignpolicy.com/story/cms.php?story_id=4056

${ }^{58}$ Lyons, Gerald. "State Capitalism: The Rise of Sovereign Wealth Funds." Standard Chartered Bank publication (19 Oct 2007$): 25$ 
- For much the same reasons as China, the Russian Stabilization Fund would not seem to give the Russian government any more political power since it has large political power as it is. Russia has a seat on the UN Security Council and is a member of other important international political organizations such as the G8 group of industrialized countries.

- The reason Russia gets a score of -2 where China received a score of -5 is due to the nature of its statecontrolled industries. In China, the state-controlled industries are remnants of communist times and utilized in its pursuit of industries that lie outside China. The Russia SWF does not make these kinds of investments overseas. Furthermore, Russia has recently reversed earlier privatization. The Yukos and Gazprom affairs and a general assault on property rights and the rule of law has resulted in many industries once again becoming stewards of the state. For sure, the best interests of the citizens are best served if privatization is allowed and property rights and the rule of law are strengthened. However, in the current state of affairs where Russian citizens have limited say, they would be best served by the SWF being used to make investments in the new state-controlled industries. As FDI dries up, the statecontrolled industries will need government funding to make further investments. Unfortunately, the motives of the Russian government in supporting state control of industries appear in many cases to be attempts at traditional political economy. For that reason, the political factor of the Russian SWF is assessed a negative score overall.

\section{Taxes $($ Score $=-1)$}

- Tax revenue as a percentage of GDP was $36.6 \%$ in 2006. Russia has a variety of taxes in place including a flat 13\% individual income tax, a corporate tax rate of 24\%, a VAT tax, a property tax and a transport tax. Government spending is low relative to revenues and represents 31\% of GDP.

- While we promote a reduction in taxes, the prevalence of corruption in Russia prevents full recognition of all the benefits. Therefore, a SWF marginally hurts citizens with a score of -1. If corruption were to decrease then this score would be lower.

- Oil and gas account for $25 \%$ of GDP and $65 \%$ of exports, but employ less than $1 \%$ of the population. The state has control over most natural resources. Manufacturing accounts for 19\% of GDP, but wage growth, capacity constraints and a rapidly developing state sector have all hurt profits in manufacturing.

\section{Infrastructure (Score $=-3)$}

- Russia has a relatively large population (142mm estimated in 2008) and thus could benefit from risk spreading across its population.

- Russia has extensive infrastructure needs. Unlike China, Russia has largely neglected these needs due to the recent growth of its economy ( $7 \%$ a year). Unfortunately, most of those gains have been from energy, leaving the Russian economy highly vulnerable to energy prices. FDI in sectors other than energy has fallen from 1.6\% of GDP in 1999 to just $0.65 \%$ in 2007. By comparison, neighboring Ukraine - who is not endowed with energy reserves - has twice the level of FDI as Russia. Productivity remains far below most developed nations and labor and capital efficiency has leveled off since the gains in the 1990s that came from spare capacity leftover from Soviet times. ${ }^{59}$ Roads and transportation systems across Russia remain old and stodgy. Vast distances separate Russian cities from one another - a poor road and transportation network only make matters worse.

\footnotetext{
${ }^{59}$ Economist, “Smoke and Mirrors," WSJ, 1 March 2008, pp. 27-9.
} 


\section{UAE}

The UAE provides an interesting analysis because of the size of the fund and the publicity it has received for lack of transparency. We feel the benefit of sharing a portion of gains with citizens is an efficient way to eliminate public concerns. Specifically, by sharing proceeds with citizens, Abu Dhabi's reputation of an opaque large government industry will be replaced with an agency that invests proceeds on behalf of citizens. Assuming 10\% annual return and a 95\% retention rate (5\% of returns distributed to citizens) each citizen would receive over $\$ 6,000$ annually. Our analysis below assumes citizens receive an annual dividend which is a fixed portion of gains. Furthermore, we assume that the size of the dividend is effectively communicated to citizens.

\begin{tabular}{|c|c|}
\hline Pros of Remitting & Cons \\
\hline - Materializes citizen's stake in SWF & $\bullet \quad$ Will require setting up administrative arm \\
- Helps establish a positive image of SWF in & \\
the international spectrum & \\
- Increases per capita income & \\
\hline
\end{tabular}

\section{Singapore}

For Singapore, we would recommend instituting a program that shares SWF capital gains with citizens; the same assumptions apply as discussed in the UAE section.

\begin{tabular}{|c|r|}
\hline Pros of Remitting & Cons \\
\hline$\bullet \quad$ Materializes citizen's stake in SWF & $\begin{array}{l}\text { Decreases the size of the SWF - whose goal } \\
\text { is to "To preserve and enhance the } \\
\text { international purchasing power of }\end{array}$ \\
$\begin{array}{l}\text { - Helps establish a positive image of SWF } \\
\text { Singapore's reserves" }\end{array}$ \\
$\begin{array}{l}\text { Singapore is already very transparent in its } \\
\text { investments, so transparency gains will not } \\
\text { be as high as others }\end{array}$ \\
$\begin{array}{l}\text { Established government practices already } \\
\text { provides a high quality of life for citizens }\end{array}$ \\
\end{tabular}

\section{Norway}

Given Norway's high tax rate our main recommendation would be to decrease the income tax. The average annual return of the fund is $\sim 8 \%$ and we feel that the cost to society of having such a high tax outweighs that return. Additionally, the fund is roughly equal to Norwegian GDP and fund value per citizen is $\sim 90 \mathrm{k}$. Average income is $\sim \$ 40 \mathrm{k}$ - assuming a $40 \%$ tax rate, the average citizen pays $16 \mathrm{k}$ in taxes. Therefore, assuming an $8 \%$ return on the SWF, a reduction in the tax rate to $30 \%$ will cost roughly half of the annual returns of the SWF. We feel this benefit will increase a citizen's desire to work and eliminate a large portion of inefficiencies created by the current tax system. 


\begin{tabular}{|c|c|}
\hline Pros of Decreasing Taxes & Cons of Decreasing Taxes \\
\hline $\begin{array}{l}\text { - Eliminates significant dead weight loss of } \\
\text { high taxes } \\
\text { Motivates citizens to work more since they } \\
\text { take home more of every dollar earned } \\
\text { - Will help position Norway's future citizens } \\
\text { to be less dependent on oil revenues. } \\
\text { O The society can focus on more } \\
\text { service type jobs }\end{array}$ & $\begin{array}{l}\text { - } \\
\text { - } \\
\text { Disbursement will increase administrative } \\
\text { costs }\end{array}$ \\
\hline
\end{tabular}

\section{Kuwait}

Kuwait situation is most similar to the UAE's. Public disclosure of fund investments is prohibited by law, which only adds to Kuwait's opaque reputation. Currently, the SWF has $\sim \$ 200 \mathrm{k}$ per citizen and consumer spending as a percentage of GDP is less than $20 \%$. Thus, we feel that Kuwait should institute an annual tax rebate. Holding our assumptions constant, the tax rebate will have the following effects:

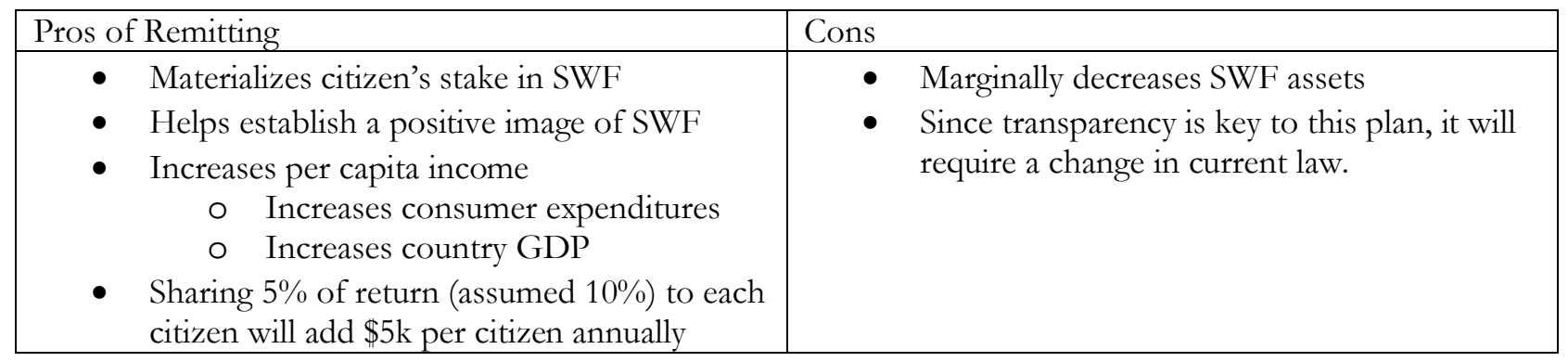

\section{China}

As discussed earlier, there are many alternative uses for China's SWF. China is already making substantial infrastructure investments, however, given its rapid growth, we feel there still capacity for those investments to grow. Most obvious is the need for railroads and the elimination of local government toll roads. In addition, China is focused on having a strong central government and remitting proceeds directly to citizens might be a threat to its power. Therefore, we would recommend instituting a policy of government funded infrastructure projects.

\begin{tabular}{|c|c|}
\hline Pros of Infrastructure Projects & Cons of Infrastructure projects \\
\hline $\begin{array}{l}\text { - Will prevent future railroad debacles such as } \\
\text { the one experienced in } 2007 \text {. } \\
\text { - Public goods will increase the quality of life } \\
\text { for many citizens. } \\
\text { - Infrastructure expenditure is less likely to } \\
\text { encounter political resistance than tax rebate } \\
\text { as it allows government to retain its strong } \\
\text { influence over the economy }\end{array}$ & $\begin{array}{l}\text { - Costs of large infrastructure projects in } \\
\text { underdeveloped rural areas can be large } \\
\text { relative to current size of SWF (\$200B) } \\
\text {. }\end{array}$ \\
\hline
\end{tabular}




\section{Russia}

The foundation of Russia's ability to earn excess returns over citizens is the lack of trust the citizens have in the system. Accordingly, funds should not be remitted to citizens before trust is restored and corruption is eliminated. Remitting funds at this state in time will not add value, we would expect citizens to keep the funds in cash and not to spend or invest the capital. Therefore, we would recommend that Russia use its proceeds to eliminate its dependencies on oil revenue. Specifically, we would recommend targeted government investments in key areas such as railroads, education, and an updated highway system.

\begin{tabular}{|l|r|}
\hline Pros of Infrastructure Projects & Cons of Infrastructure projects \\
\hline$\bullet \quad$ Eliminates the SWF & $\bullet \quad$ Drastic change in government program. \\
- Will eliminate future generations' & $\bullet \quad$ Large bureaucratic projects may increase \\
dependencies on oil revenues & \\
- Public goods will increase the quality of life \\
for all citizens.
\end{tabular}




\section{CONCLUSION}

Sovereign wealth funds exist for a wide variety of explicit and implicit reasons, and operate under different governance structures and investment policies. They also serve the interests of citizens and governments whose economic and political contexts are more diverse still. Evaluating the relative costs and benefits of sovereign wealth funds and their alternatives requires many simplifying assumptions and qualitative assessments. Furthermore, as we have demonstrated, the benefits of SWFs must be analyzed on a case by case basis. The analysis is complicated by the opacity of many of the funds and the difficulty of determining the extent of their political motivations and the returns on those objectives. In this paper our aim was to provide an overview of the wide spectrum of SWFs in operation today, to weigh the merits of some potential alternative uses of the funds, to consider some of the non-financial benefits of SWFs and their effects on the economic analysis, and finally, to summarize the benefits SWF provide for their respective citizens.
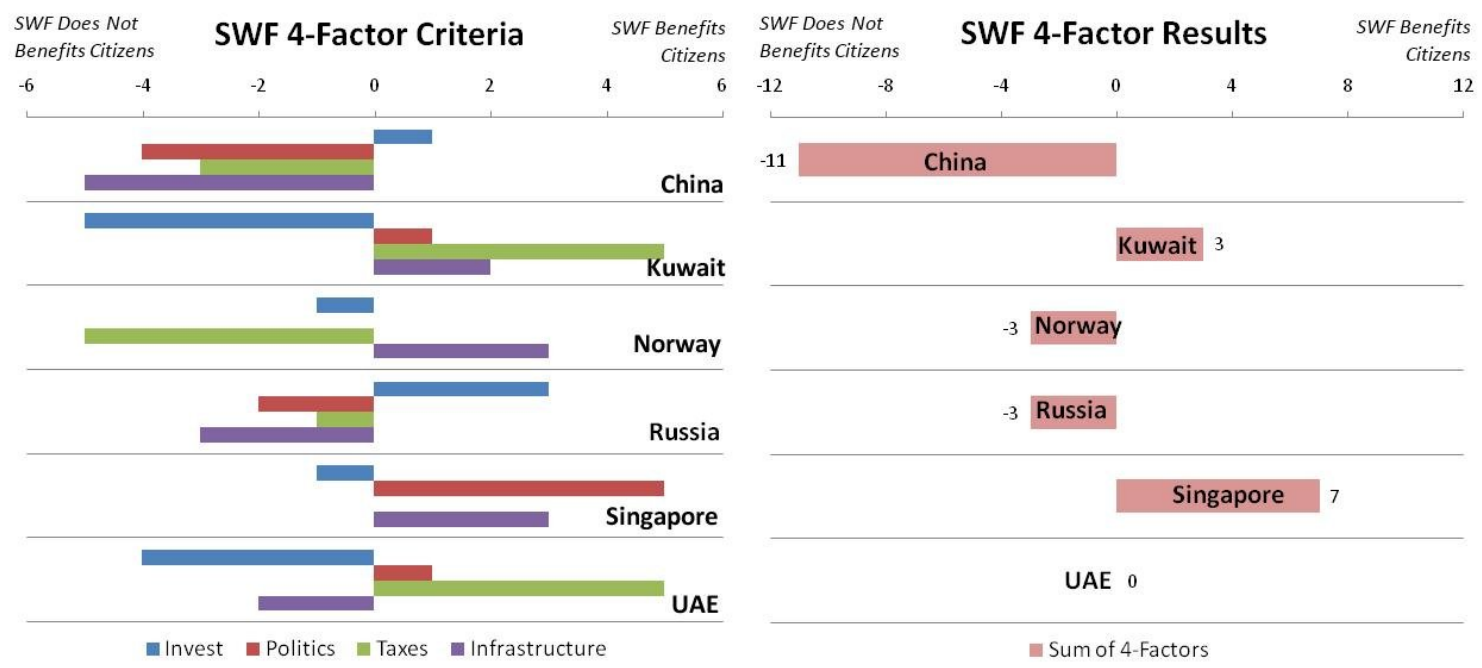

The four factor model above summarizes the benefits SWFs provide to citizens for the six funds identified. The overall scores vary from (-11) in China to (+7) in Singapore. We applied equal weight to each of the four factors; however, an alternative weighting scheme may be appropriate for different studies and audiences. Our analysis focused on the benefits SWFs provide to citizens for the six largest funds. Only Singapore and Kuwait provide an overall net benefit to citizens based on our analysis, with Singapore's benefits outweighing Kuwait's. We have concluded that most SWFs do not benefit citizens and would thus recommend other uses for the funds. We have addressed several alternatives throughout this paper and would emphasize the importance of aligning citizens' preferences with the funds and beginning any remittance packages slowly. 

APPENDIX 1 - TABLE OF STATISTICS FOR SWFS

\begin{tabular}{|c|c|c|c|c|c|c|}
\hline Country & $\begin{array}{l}\text { UAE } \\
\text { (Combined) }\end{array}$ & $\begin{array}{l}\text { Singapore } \\
\text { (Combined) }\end{array}$ & Norway & Kuwait & China & Russia \\
\hline Value (\$B) & 875 & 490 & 380 & 250 & 200 & 148 \\
\hline Source of SWF Revenue & Oil & High Savings Rate & Oil & Oil & FX Reserves & Oil \\
\hline Rationale / Mission of SWF & $\begin{array}{l}\text { Unknown; limited } \\
\text { disclosure }\end{array}$ & $\begin{array}{l}\text { Long- and mid- } \\
\text { term returns; } \\
\text { Activist investor; } \\
\text { Domestic industry } \\
\text { development }\end{array}$ & $\begin{array}{l}\text { Long-term } \\
\text { returns; } \\
\text { Ethical } \\
\text { investments only; } \\
\text { Diversification of } \\
\text { oil revenue }\end{array}$ & $\begin{array}{l}\text { Long-term } \\
\text { returns; } \\
\text { Reputation of } \\
\text { financial expertise }\end{array}$ & $\begin{array}{l}\text { High returns; } \\
\text { Social and political } \\
\text { gains; } \\
\text { Domestic industry } \\
\text { development }\end{array}$ & $\begin{array}{l}\text { Reduce } \\
\text { inflationary } \\
\text { pressures; } \\
\text { Economic } \\
\text { stabilization of } \\
\text { export volatility }\end{array}$ \\
\hline Average annual return & $\mathrm{N} / \mathrm{A}$ & $\begin{array}{l}\text { GIC: } 9.5 \% \text { /year } \\
\text { since } 1981 \text {; } \\
\text { Temasek: } 27 \% \text { for } \\
\text { FY2007 }\end{array}$ & $8.50 \%$ & $\mathrm{~N} / \mathrm{A}$ & $\begin{array}{l}\mathrm{N} / \mathrm{A} \\
\text { Fund was initiated } \\
\text { last year. }\end{array}$ & $\mathrm{N} / \mathrm{A}$ \\
\hline Growth rate & $10 \%$ in FY06 & $\begin{array}{l}\text { GIC: N/A } \\
\text { Temasek: } 35 \% \text { in } \\
\text { FY07 }\end{array}$ & $28 \%$ in $\mathrm{FY} 06$ & $30 \%$ in $\mathrm{FY} 06$ & $\begin{array}{l}\text { Fund initiated in } \\
2007\end{array}$ & $96 \%$ in $\mathrm{FY} 07$ \\
\hline Fund Value as $\%$ of GDP & $521 \%$ & $169 \%$ & $93 \%$ & $265 \%$ & $8 \%$ & $14 \%$ \\
\hline Per capita GDP & $\$ 49,700$ & $\$ 30,900$ & $\$ 47,800$ & $\$ 21,600$ & $\$ 7,600$ & $\$ 12,100$ \\
\hline Average Income & $\$ 16,471$ & $\$ 24,180$ & $\$ 43,350$ & $\$ 16,340$ & $\$ 1,100$ & $\$ 8,920$ \\
\hline Income tax rates on citizens & $0 \%$ & Up to $18.0 \%$ & Up to $47.8 \%$ & $0 \%$ & Up to $45 \%$ & Flat $13 \%$ \\
\hline Tax revenue as $\%$ of GDP & $2.10 \%$ & $12.90 \%$ & $43.60 \%$ & $1.00 \%$ & $15.80 \%$ & $36.60 \%$ \\
\hline Gov't spending as \% of GDP & $25.70 \%$ & $14.40 \%$ & $42.30 \%$ & $29.10 \%$ & $30.00 \%$ & $31.90 \%$ \\
\hline Inflation & $9.10 \%$ & $0.90 \%$ & $2.00 \%$ & $3.10 \%$ & $1.80 \%$ & $12.70 \%$ \\
\hline $\begin{array}{l}\text { GDP Growth } \\
\text { (5-year CAGR through 2005) }\end{array}$ & $8.10 \%$ & $5.70 \%$ & $2.30 \%$ & $9.90 \%$ & $9.90 \%$ & $6.40 \%$ \\
\hline SWF Transparency & Very Low & High & High & Low & Low & High \\
\hline Barriers to Private Investment & Low & Very Low & Very Low & Very Low & High & Very High \\
\hline Government Corruption & Moderate & Low & Low & High & High & High \\
\hline
\end{tabular}




$$
\begin{aligned}
\varepsilon_{\mathrm{df}}=\varepsilon_{\mathrm{D}} / \delta- & {[(1-\delta) / \delta]^{*} \varepsilon_{\mathrm{S}} } \\
\text { where: } & \varepsilon_{\mathrm{df}}=\text { elasticity of the dominant firm } \\
& \varepsilon_{\mathrm{D}}=\text { market elasticity of demand } \\
& \varepsilon_{\mathrm{S}}=\text { market elasticity of supply } \\
& \delta=\text { market share of the dominant firm }
\end{aligned}
$$

As seen in the above equation, three main parameters are needed: elasticity of demand, elasticity of supply, and market share.

\section{APPENDIX 3 - DEADWEIGHT LOSS AND TAXES}

In order to understand the effect of taxes, we look at a basic example of taxing consumption of a given good as seen in the graph on the left below. It is important to note that before taxes, the initial equilibrium is at point $\left(\mathrm{Q}^{*}, \mathrm{P}^{*}\right)$. After implementing a tax (of amount $\mathrm{P}_{2}-\mathrm{P}_{1}$ ) the total tax received by the government is $\left(\mathrm{P}_{2}\right.$ $\left.-\mathrm{P}_{1}\right) * \mathrm{Q}_{1}$. Additionally, the decreased quantity causes a deadweight loss - represented by $\mathrm{P}_{2}, \mathrm{P}_{1}, \mathrm{Q}^{*}$.

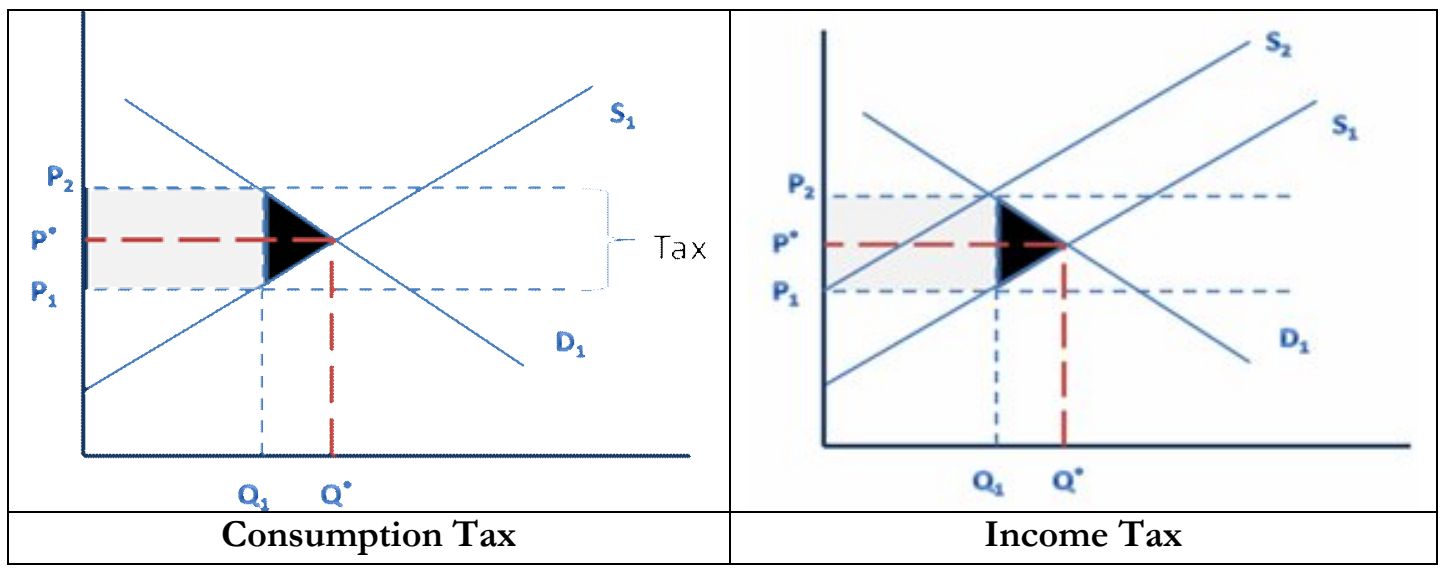

The portion of the tax revenue paid by consumers and suppliers is beyond the scope of this paper, but is dependent on relative elasticities of supply and demand as well as the change in quantity. The consumer's portion of the tax is $\left(\mathrm{P}_{2}-\mathrm{P}^{*}\right) * \mathrm{Q}_{1}$ while producer's tax is $\left(\mathrm{P}^{*}-\mathrm{P}_{1}\right) * \mathrm{Q}_{1}$. The deadweight loss caused by this tax is calculated below.

$$
\mathrm{DWL}=\frac{1}{2}(\mathrm{P} * \mathrm{Q}) * \mathrm{~T}^{2} *\left[\frac{1}{\left(\frac{1}{\epsilon^{D}}-\frac{1}{\epsilon^{S}}\right)}\right]
$$

The effect of consumption taxes is shown for comparison. The effect of income taxes is similar and can be found in the graph on the right- the initial supply of labor $\left(\mathrm{S}_{1}\right)$ is shifted to the left $\left(\mathrm{S}_{2}\right)$ after the implementation of an income tax $\left(\mathrm{P}_{2}-\mathrm{P}_{1}\right)$. 


\section{APPENDIX 4 - CONSUMPTION ANALYSIS}

(1) $\mathrm{P}_{\mathrm{x}}{ }_{\mathrm{x}} \mathrm{x}+\mathrm{P}_{\mathrm{y}}{ }^{\mathrm{y}} \mathrm{y}=$ Income where: $\mathrm{x}=$ consumption; $\mathrm{y}=$ leisure

(2) $\mathrm{MUx} / \mathrm{Px}=\mathrm{MUy} / \mathrm{Py} \quad$ where: $\mathrm{Px}=\mathrm{CPI}$ or similar; $\mathrm{Py}=$ price of leisure (after-tax real wage)

If we are to suppose that the government subsidizes each citizen with his/her allocation, there are several factors to consider. First, we examine savings and consumption. Household savings can be defined as:

$$
\mathrm{S}_{1}=\left(\mathrm{W}_{0}+\mathrm{SUB}+\mathrm{Y}_{1}\right)-\mathrm{C}_{1}
$$

Households have some initial wealth $\left(\mathrm{W}_{1)}\right.$, receive a subsidy (SUB) and have income of $\left(\mathrm{Y}_{1}\right)$ while also consuming (c). If we take this analysis into time period 2, the maximum a household can consume is:

$$
\begin{aligned}
& \mathrm{C}_{2}=\mathrm{S}_{1} *(1+\text { return })+\mathrm{Y}_{2} \\
& \mathrm{C}_{2}=\left(\left(\mathrm{W}_{0}+\mathrm{SUB}+\mathrm{Y}_{1}\right)-\mathrm{C}\right) *(1+\text { return })+\mathrm{Y}_{2}
\end{aligned}
$$

Accordingly:

$$
\mathrm{C}_{1}+\mathrm{C}_{2} /(1+\mathrm{r})=\mathrm{W}_{0}+\mathrm{SUB}+\mathrm{Y}_{1}+\mathrm{Y}_{2} /(1+\mathrm{r}) \text {. }
$$

$\mathrm{C}_{2}$ and $\mathrm{Y}_{2}$ is all future discounted consumption and income

Finally, we want to maximize the equation above subject to the household utility function of:

$$
\mathrm{U}\left(\mathrm{C}, \mathrm{C}_{2}\right)=\ln (\mathrm{c})+\beta \ln \left(\mathrm{C}_{2}\right)
$$

The utility function states that the larger value one places on future consumption $(\beta)$ the less individuals will consume today. Next, we maximize utility given that:

$$
\ln (\mathrm{c})+\beta \ln \left(\left(\left(\mathrm{W}_{0}+\mathrm{SUB}+\mathrm{Y}_{1}\right)-\mathrm{C}\right) *(1+\text { return })+\mathrm{Y}_{2}\right)
$$

In order to maximize utility we take the derivative with respect to $C$ and set $=$ to 0 :

1. $\mathrm{C}_{2}=\beta(1+$ return $) * \mathrm{C}$

2. $\mathrm{C}_{2}=\left(\left(\mathrm{W}_{0}+\mathrm{SUB}+\mathrm{Y}_{1}\right)-\mathrm{C}\right) *(1+$ return $)+\mathrm{Y}_{2}$

3. $C_{1}=\left[\left(\mathrm{W}_{0}+\mathrm{SUB}+\mathrm{Y}\right) /(1+\right.$ return $\left.)+\mathrm{Y}_{2}\right] /[(1+\beta)(1+$ return $)]$

Here we can see the income and substitution effect again: Assuming an increase in the return - individuals will have more disposable income and consume more (income effect) while $\mathrm{C}_{1}$ decreases since one receives a higher return for every dollar saved (substitution effect).

If we assume that most people are net savers, it is important to note two important aspects:

1. The change in current consumption depends on the relative magnitude of the income and substitution effects. 
2. An increase in return will cause an increase in future consumption regardless of the income and substitution effects.

\section{APPENDIX 5 - MACRO CONSUMPTION ANALYSIS}

We have determined that consumption will increase upon a decrease in taxes or issuance of a tax rebate, we can explore the macroeconomic effects of this decision. An increase in consumption causes a shift to the right in the IS (investment-savings) and AD (aggregate demand) curves from points IS0 and AD0 to IS1 and AD1. The shift in the aggregate demand curve results in higher prices (to P1) and, at higher prices, firms will produce more, resulting in a short-run increase in output (to Y1). Higher prices (at P1) also results in a decrease in the real money supply in the money market. As prices increase, buying power decreases, shifting the LM (money supply or liquidity for money) curve to the left. This leftward shift, coupled with the rightward shift in the IS curve increases interest rates, which results in a decrease in firms' investments. Investment should not decrease by more than the increase in consumption, which leaves short-run output higher than the long run aggregate supply. The final step in the short-run analysis is to look at the labor market. The increase in prices to P1 lowers the real wage to w0/p1, knocking the labor market out of equilibrium. The labor supply does not react to the lower real wage, leaving labor supply higher than equilibrium at the market clearing rate.

The first step in the long-run analysis is the self-correcting mechanism of the labor market. Nominal wages (W) will increase to restore equilibrium to the labor market, otherwise supply would decrease to a level that could not produce aggregate demand. The increase in nominal wages increases the cost of production and shifts the short-run aggregate supply (SRAS curve) to the left. This leftward shift in SRAS pushes prices higher, from $\mathrm{P} 1$ to $\mathrm{P} 2$. The labor market will settle into equilibrium where W1/P2 equals the starting point equilibrium of W0/P0. The increase to P2 will decrease real money supply further, shifting the LM curve to the left again and pushing interest rates higher, to $\mathrm{r} 2$. Investment will fall a little further as interest rates increase again. Consumption will not increase more than the initial short-run increase; IS1 and AD1 are the new long-run curves. In the money market, output $(\mathrm{Y})$ will return to its original level. In the aggregate market, Y will return to its original long-run aggregate supply level. Output has not changed but prices, nominal wages and interest rates are all higher.

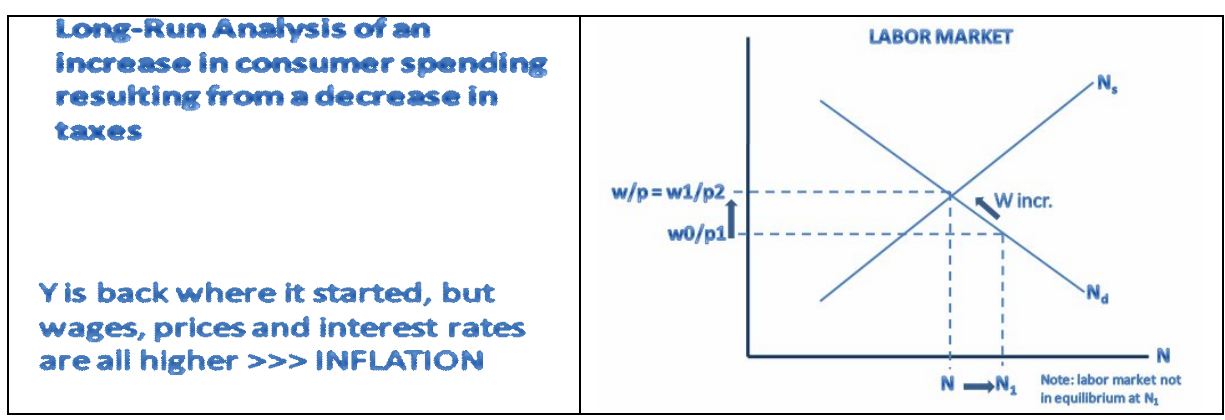




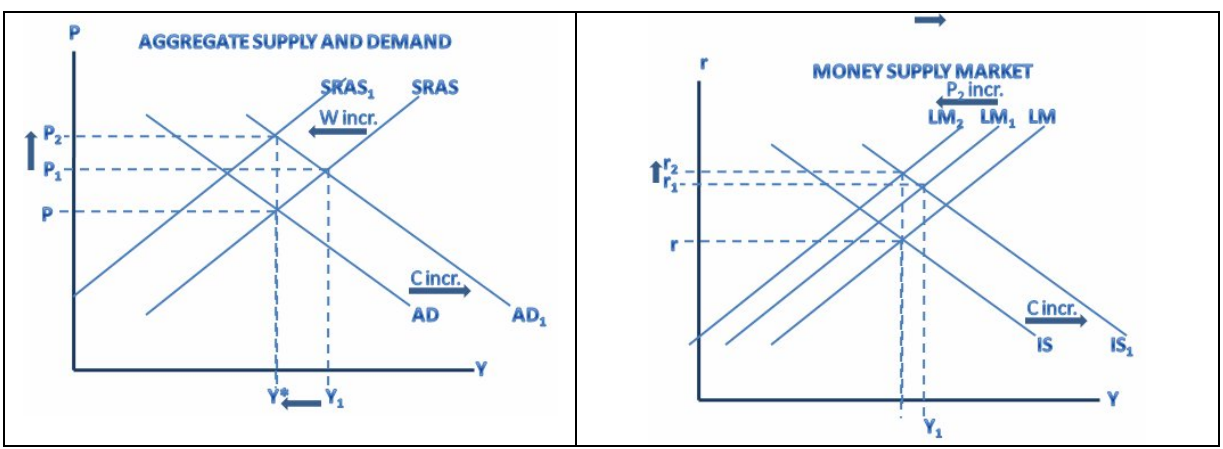

APPENDIX 6 - RIO TINTO-BHP CASE STUDY

This case study analyzes whether monopoly pricing will result from the proposed Rio Tinto-BHP merger and whether intervention to block the merger by China's SWF is justified. In 2008, Chinalco - a state-owned Chinese aluminum giant - initiated an unsolicited offer for a $\$ 14$ billion, 9\% stake in Rio Tinto, an Australian mining company. Rio Tinto is currently the target of a takeover by BHP Billiton (English mining company). If the merger goes through, a combined Rio Tinto-BHP would control more about $32 \%$ of the world's iron ore. Chinalco's bid is financed by the China Development Bank (China's SWF) and $\$ 1.2$ billion of the offer was made on behalf of Alcoa, the U.S. aluminum company. These facts have raised concerns that a SWF is being used for financial activism and political purposes. ${ }^{60}$ In fact, officials of the China Development Bank have made comments to the press of these concerns. Some have alleged that Alcoa agreed to participate to gain access to Chinese markets. To this point, the debate surrounding such uses of SWF funds has assumed that the motives would be "to interfere in the private market's normal, healthy search for efficiency and profit" (as WSJ editors stated, echoing comments made by Summers at Davos). In fact, the CDB has "social and political returns" as one of its stated objectives in addition to its financial ones. ${ }^{61}$ Complicating matters further is that many SWFs lack transparency and do not announce intentions.

The following is the situation faced by China: the majority of increases in global raw materials will be borne by their citizens and their export-driven manufacturing sector. China fears that a Rio Tinto-BHP merger would allow the conglomerate to set monopoly prices on iron ore, increases that would mostly be borne by Chinese consumers and firms. In fact, if Rio Tinto-BHP is a profit-maximizing firm, they will optimally choose to do so. The governments of the UK and Australia will probably not interfere because most of the additional cost will be borne by China. Yes, some Chinese-produced exports will rise in price, but since Western consumers are relatively elastic, the price increases will be minimal.

Some may argue that any such carteling of iron ore would be muted by the difficulties cartels have had historically. For example, initial fears surrounded OPEC in the 1970s, but the number of firms and nations in that cartel and their incentives to cheat has resulted in prices closer to the efficient level than the monopoly level. The case with iron-ore is different; three major firms dominate the market internationally and a Rio Tinto-BHP merger would further consolidate it. China could act to prevent the merger through domestic

${ }^{60}$ H.W. Jenkins, "Deal(s) of the Century," WSJ, 6 Feb 2008, p. A18.

${ }^{61}$ Lyons, "State Capitalism: The Rise of Sovereign Wealth Funds," p. 24. 
laws, much as the EU did in the case if the CVRD-Caemi merger, but Rio Tinto and BHP do not operate on Chinese soil - Chinese steel-makers import sea-borne iron ore.

The dominant firm model from Appendix 1.2 can be applied to measure monopoly power. In two past studies, the elasticity of iron ore was determined to be low - measured empirically at 0.15 and $0.18 .{ }^{62}$ However, the authors of this study raise the concern that this estimate may not be the long-term elasticity and therefore too low. They use 0.4 but also elasticities of 1.0 and 2.0.63 An Australian study estimated iron ore elasticity of supply for mining and ore companies; their short-term measured elasticity was 0.61and their longterm elasticity was $4.61 .{ }^{64}$

The last parameter needed is market share. According to a recent article in the WSJ, a combined Rio TintoBHP would control $32 \%$ of global iron ore; currently, BHP controls $15 \%$ and Rio Tinto controls $17 \% .{ }^{65}$

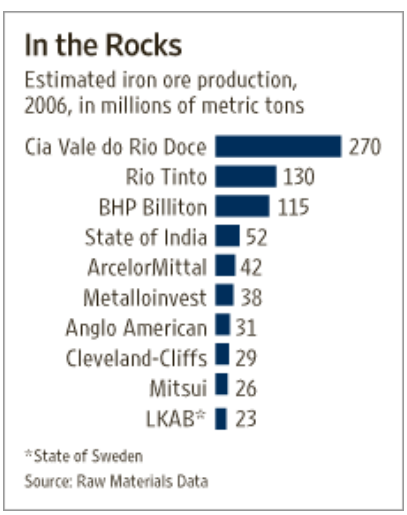

The calculations below include the pre-merger and merged shares - $15 \%$ versus $32 \%$-- and a higher $70 \%$ for comparison. Using these numbers and the dominant firm model results in the following:

\footnotetext{
${ }^{62}$ H.S. Chang, "Estimating Japanese Import Shares of Iron Ore," Resources Policy, 1994; S. Hellmer, "Competitive Strength in Iron Ore Production," Lulea University of Technology, 1997.

${ }^{63}$ Lundmark and Nilsson, p. 116-7.

${ }^{64}$ K.G. Williams and R.W. Fraser, "State Taxation of the Iron Ore Industry in Western Australia," Australian Economic Review, 1985.

${ }^{65}$ P. Barta and S. Moffett, “Accords Set Stage for Iron-Ore Price Surge,” WSJ, 19 Feb 2008, A2.
} 


\begin{tabular}{|c|c|c|c|c|}
\hline Dominant Fir & sticit & Deman & naded & \\
\hline Scenario 1: & $\overline{\text { t State }}$ & & & \\
\hline Mkt Share = & $15 \%$ & Elastic & Deman & \\
\hline & & -0.4 & -1.0 & -2.0 \\
\hline Elasticity of & 0.61 & -6.12 & -10.12 & -16.79 \\
\hline Supply (Es) & 4.61 & -28.79 & -32.79 & -39.46 \\
\hline Scenario 2: & $\overline{t o-B H}$ & $\mathrm{rge}$ & & \\
\hline Mkt Share = & $32 \%$ & Elastic & Deman & \\
\hline & & -0.4 & -1.0 & -2.0 \\
\hline Elasticity of & 0.61 & -2.55 & -4.42 & -7.55 \\
\hline Supply (Es) & 4.61 & -11.05 & -12.92 & -16.05 \\
\hline Scenario 3: & $\overline{\text { mark }}$ & are sho & or comp & \\
\hline Mkt Share = & $70 \%$ & Elastic & Deman & \\
\hline & & -0.4 & -1.0 & -2.0 \\
\hline Elasticity of & 0.61 & -0.83 & -1.69 & -3.12 \\
\hline Supply (Es) & 4.61 & -2.55 & -12.92 & -16.05 \\
\hline
\end{tabular}

These results show that even if a merger results in a combined Rio Tinto-BHP market share of $32 \%$, the combined firm will lack market power. In the short-term, the elasticity of demand for the dominant firms remains significantly price elastic. It is even more so in the long-term. At the $70 \%$ market share level, the elasticity of the dominant firm becomes relatively inelastic but it is still relatively elastic over the long-term. In summary, a Rio Tinto-BHP merger should not result in Chinese firms and consumers being charged a monopoly price. Even at high share levels, enough supply exists for fringe firms to push the price down to the competitive level. However, what this analysis does not consider is a directed effort at collusion among the remaining ore producers. What can be said is that monopolistic behavior will not result from mere consolidation. Therefore, a SWF could be justified to deter collusion of iron ore pricing but is not required to deter monopoly pricing of iron ore. 


\section{BIBLIOG RAPHY}

_. “America’s Splurge." E conomist (February 16, 2008): 32.

. "Chinese citizens allowed to invest in London stock market through commercial banks." [online] 25 February 2008.

http://www.insurancenewsnet.com/article.asp?n=1\&innID=20071218375.8_2ecf003f6e500f78

. "Happy Family" The economist. (February 7th 2008): 9

- "NCB's Said Al-Shaikh Urges Saudi Arabia To Set Up Sovereign Fund"

http://www.zawya.com/story.cfm/sidv51n03-3NC23

. "Norway liberalizes exchange controls." Business A merica (September 3, 1984).

. "Permanent Income Hypothesis." 1 February 2008. http://www.economist.com/research/

Economics/alphabetic.cfm?letter $=\mathrm{P}$

. "Rushing on by Road, Rail, and Air." Economist (16 February 2008): p. 30-2.

. "Russia’s Economy: Smoke and Mirrors.” Economist (March 1, 2008): 27-9.

Ahuja, H.L. Macroeconomics - Theory and Policy. New Dehli: S. Chand \& Company Ltd, 2004.

Arrow, Ken and R.C. Lind. "Uncertainty and the Evaluation of Public Investment Decisions," A merican E conomic Review (1970).

Åslund, Anders. “The Truth About Sovereign Wealth Funds.” Foreign Policy. December 2007.

http://www.foreignpolicy.com/story/cms.php?story_id=4056

Barnett, Thomas O. "Maximizing Welfare Through Technological Innovation," DOJ Anti-Trust Diviision, speech at George Mason University, 31 Oct 2007. Available at

http://www.usdoj.gov/atr/public/speeches/227291.htm

Barta, Patrick and Sebastian Moffett. “Accords Set Stage for Iron-Ore Price Surge.” W all Street Journal (February 19, 2008): A2.

Chang, H.S. “Estimating Japanese Import Shares of Iron Ore.” Resources Policy 20 (1994): 87-93.

Davis, Bob. “State Funds May Not Bolster Freedoms.” W all Stręt Journal (February 11, 2008): A2.

Davis, Bob. "U.S. Pushes Sovereign Funds to Open to Outside Scrutiny," W all Street Journal (February 26, 2008): A1.

Dwinnell, Tate. “2030 Projections for the Oil \& Gas Industry.” Self Investors website, 17 January 2008. 
http://selfinvestors.com/tradingstocks/industry-spotlight/2030-projections-for- the-oil-gas-industry/

Epley, Nicholas and Ayelet Gneezy. "The Framing of Financial Windfalls and Implications for Public Policy." Journal of Socio-E wnomics (February 2007): $36-47$.

Fialka, John J. War by Other Means: Economic Espionage in America. New York: Norton, 1997.

Gilpin, Robert. Global Political Economy: Understanding the Economic Political Order. Princeton: Princeton University Press, 2001.

Gustafson, Thane. Capitalism Russian-Style. Cambridge: Cambridge University Press, 1999.

He, Xinhua and Yongfu Cao. "Understanding High Saving Rate in China." China \& W orld E conomy 15.1 (2007): 1-13.

Hellmer, S. "Competitive Strength in Iron Ore Production.” Doctoral Thesis - Lulea University of Technology, 1997:3.

Hsieh, Chang-Tai. "Do Consumers react to anticipated Income Changes? Evidence from the Alaska Permanent Fund" E conomic Review. December 2005.

Jen, Stephen and Oliver Weeks. "Celebrating the Birth of Russia’s SWF." M organ Stanley Research G lobal (January 2008): $1-2$.

Jenkins, Holman W. "Deal(s) of the Century." W all Street Journal (Feb 6, 2008): A18.

Johnson, David S. Parker, Jonathan and Souleles, Nicholas "Household Expenditure and the Income Tax Rebates of 2001" N ational Bureau of E conomic Research. August 2005.

Kaluga, Moscow and Nizhny Novogorod, “Smoke and Mirrors.” E conomist (1 Mar 2008): 27-9.

Kimmitt, Robert M. "Public Footprints in Private Markets." Foreign A ffairs (January/February 2008). http://www.foreignaffairs.org/20080101 faessay87109/robert-m-kimmitt/public-footprints-in-private markets.html

Klein, Michael. "Risk, Taxpayers, and the Role of Government in public and private finance for Project Finance,” 1996, The World Bank, Policy Research Working Paper 1688.

Landrum, Bruce D. "The Globalization of Justice: The Rome Statute of the International Criminal Court," in The A rmy L awyer, Charlottesville: September 2002.

Lundmark, Robert and Mats Nilsson. "What Do Economic Simulations Tell Us? Recent Mergers in the Iron Ore Industry.” Resourœes Policy (March 19, 2003).

Lyons, Gerald. "State Capitalism: The Rise of Sovereign Wealth Funds." Standered Chartered Bank publication (19 Oct 2007). 
Maremont, Mark. "Will the Prince Turn Pauper? Billions Later, Jefri’s in a Royal Mess.” W all Street Journal (Mar 1, 2008): A1,6.

Martin, Michael. “China’s Sovereign Wealth Fund.” Congressional Research Service report to Congress, January 22, 2008.

Medas, Paulo and Eric Le Borgne. "Sovereign Wealth Funds in the Pacific island Countries: Macro-Fiscal Linkages,” International Monetary Fund Woking Paper, 2007.

Norges Bank Investment Management. “2006 Annual Report.” Oslo, 2006. http://www.norgesbank.no/Pages/Report__65334.aspx

OECD. "Economic Outlook.” No. 78,Vol 2005,Issue 2. Paris, 2005.

Rybinski, Krzysztof and Urszula Sowa. “Global Reserves Management.” Working Paper, National Bank of Poland (May 2007). Available at SSRN: http://ssrn.com/abstract=985071

Sanders, Doug. "Frugal Norway Saves for Life after the Boom." G lobe and M ail (January 31, 2008). http://www.theglobeandmail.com/servlet/story/RTGAM.20080130.w-OSmain31/BNStory/oilsands/feature-topic?pageRequested=all

Solow, Robert M. A Contribution to the Theory of Economic Growth. 70 Quarterly Journal of Economics (1956).

Steil, Benn. “California’s Sovereign Wealth Fund.” W all Street Journal (March 7, 2008): A14.

U.S. Department of State. "Russia.” [online] February 1, 2008. http://www.state.gov/e/eeb/ ifd/2007/88898.htm

U.S. Energy Information Administration. "World Crude Oil Prices.” [online] February 1, 2008. http://tonto.eia.doe.gov/dnav/pet/pet_pri_wco_k_w.htm

Williams, K.G. and R.W. Fraser. "State Taxation of the Iron Ore Industry in Western Australia." A ustralian E conomic Review (1985:1): 30-6.

Young, Alwyn. "Lessons from the East Asian NICs: A Contrarian View." NBER Working Paper 4482, 1993 and "The Tyranny of Numbers: Confronting the Statistical Realities of the East Asian Growth Experience.” NBER Working Paper 4680, 1994. 